Document downloaded from:

http://hdl.handle.net/10251/139936

This paper must be cited as:

Berenguer, R.; La Rosa-Toro, A.; Quijada, C.; Morallon, E. (2017). Electrocatalytic Oxidation of Cyanide on Copper-doped Cobalt Oxide Electrodes. Applied Catalysis B Environmental. 207:286-296. https://doi.org/10.1016/j.apcatb.2017.01.078

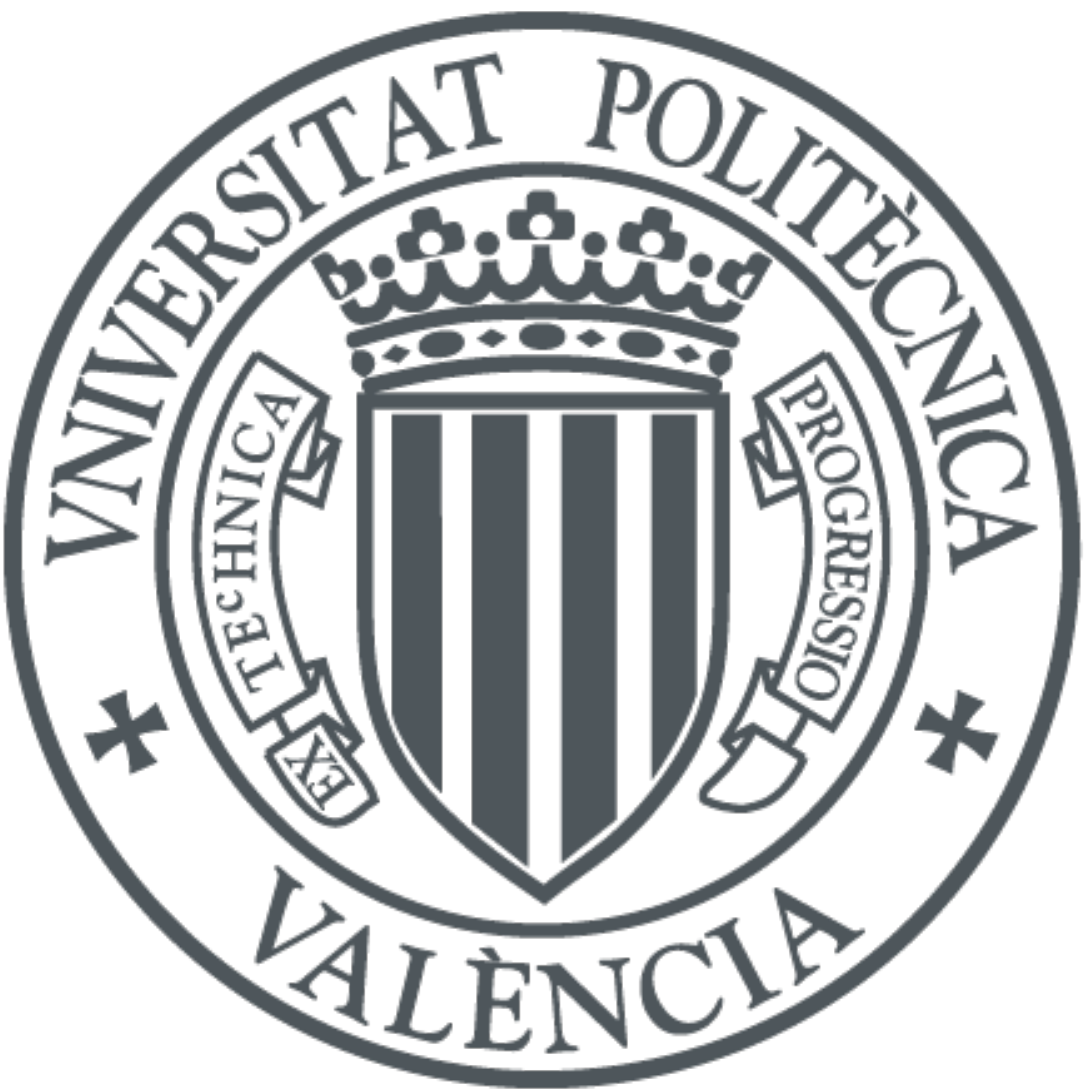

The final publication is available at

https://doi.org/10.1016/j.apcatb.2017.01.078

Copyright Elsevier

Additional Information 


\section{Accepted Manuscript}

Title: Electrocatalytic Oxidation of Cyanide on Copper-doped Cobalt Oxide Electrodes

Author: R. Berenguer A. La Rosa-Toro C. Quijada E. Morallón

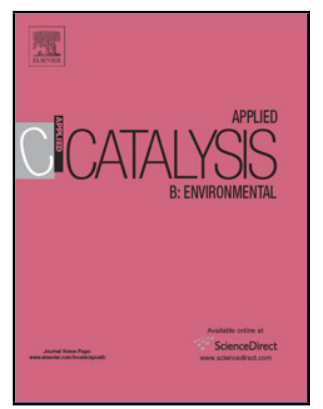

PII: S0926-3373(17)30095-4

DOI: http://dx.doi.org/doi:10.1016/j.apcatb.2017.01.078

Reference: APCATB 15391

To appear in: Applied Catalysis B: Environmental

Received date: 3-10-2016

Revised date: 12-1-2017

Accepted date: 28-1-2017

Please cite this article as: R. Berenguer, A. La Rosa-Toro, C. Quijada, E. Morallón, Electrocatalytic Oxidation of Cyanide on Copper-doped Cobalt Oxide Electrodes, Applied Catalysis B, Environmental (2017), http://dx.doi.org/10.1016/j.apcatb.2017.01.078

This is a PDF file of an unedited manuscript that has been accepted for publication. As a service to our customers we are providing this early version of the manuscript. The manuscript will undergo copyediting, typesetting, and review of the resulting proof before it is published in its final form. Please note that during the production process errors may be discovered which could affect the content, and all legal disclaimers that apply to the journal pertain. 


\title{
Electrocatalytic Oxidation of Cyanide on Copper-doped Cobalt Oxide Electrodes
}

\author{
R. Berenguer ${ }^{\mathrm{a}}$, A. La Rosa-Toro ${ }^{\mathrm{b}}$, C. Quijada $^{\mathrm{c}}$, E. Morallón $^{\mathrm{a}}$

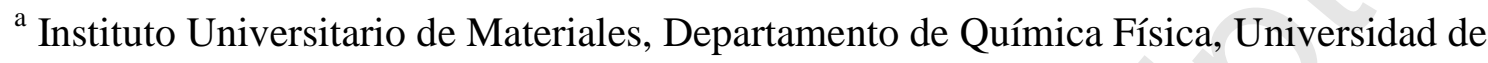 \\ Alicante, Apartado 99, 03080-Alicante, Spain \\ ${ }^{\mathrm{b}}$ Facultad de Ciencias, Universidad Nacional de Ingeniería, Av. Tupac Amaru, 210, Lima (Peru) \\ ${ }^{c}$ Departamento de Ingeniería Textil y Papelera, Universitat Politècnica de València. Pza. \\ Ferrándiz y Carbonell, 03801 Alcoy (Alicante). Spain
}

\begin{abstract}
Copper and copper oxides are well-known excellent catalysts in several chemical processes, but their low mechanical and electrochemical stability restrict their direct utilization as electrodes in electrolytic processes. In this work, the incorporation of copper into cobalt oxide $\left(\mathrm{Cu}_{\mathrm{x}} \mathrm{Co}_{3-\mathrm{x}} \mathrm{O}_{4}\right)$ is presented as an excellent approach to obtain highly active and robust copper-based electrocatalysts. Particularly, the electrocatalytic performance of Ti-supported $\mathrm{Cu}_{\mathrm{x}} \mathrm{Co}_{3-\mathrm{x}} \mathrm{O}_{4}$ electrodes (with $0 \leq \mathrm{x} \leq 1.5$ ) has been studied for the oxidation of cyanide in alkaline media. Cyclic voltammetry and electrolysis runs show an outstanding effect of $\mathrm{Cu}$ on the activity, efficiency and kinetics of spinel $\mathrm{Cu}_{\mathrm{x}} \mathrm{Co}_{3-\mathrm{x}} \mathrm{O}_{4}$ electrodes for $\mathrm{CN}^{-}$electro-oxidation. Despite being active oxides with high activity towards water oxidation, copper saturated $(\mathrm{x}=1.0)$ and oversaturated $(\mathrm{x}=1.5)$ spinels exhibit unprecedented $100 \%$ current efficiencies for the electrooxidation of $\mathrm{CN}^{-}$in aqueous electrolyte. In-situ surface enhanced Raman spectroscopy (SERS) reveals the specific adsorption of $\mathrm{CN}^{-}$ions on surface $\mathrm{Cu}$ species to be involved in the electrocatalytic oxidation mechanism. This electrocatalytic activity has been attributed to surface $\mathrm{Cu}(\mathrm{II})$ in the spinel lattice. Furthermore, the $\mathrm{Cu}_{\mathrm{x}} \mathrm{Co}_{3-\mathrm{x}} \mathrm{O}_{4}$ electrodes also display high
\end{abstract}


electrochemical stability. Therefore, they are considered excellent candidates for the sustainable electrochemical elimination of highly toxic cyanides.

Corresponding author

E. Morallón

morallon@ua.es

Telf. 34-965909590

Fax: 34-965903537 


\section{Introduction}

Copper and copper oxides have unique catalytic performance for several chemical processes of major industrial interest [1-5]. In addition, they are very attractive for multiple electrochemical processes and devices [6-11]. Despite such relevance, however, their utilization as electrodes and/or electrocatalysts in electrolytic treatments is greatly restricted by their low mechanical and electrochemical stability [6,11-13]. Hence, the design and development of robust and stable $\mathrm{Cu}-$ based electrocatalysts may bring a new generation of active components for multiple electrochemical devices and applications.

Among electrolytic processes, the anodic oxidation of environmental pollutants is considered a powerful technique in wastewater treatment for the abatement (destruction) of refractory and toxic compounds that cannot be removed by conventional biological treatments [14]. A good example of this kind of pollutants is cyanide, which provokes environmental and biological contamination in surface and ground water [15-17]. Cyanides are widely utilized in large scale industrial processes [16,17] and commonly found in effluents from oil refineries and thermoelectric power stations $[16,18]$, thereby being inevitably released into the environment. As a result, cyanide has been designated as an Environmental Protection Agency (EPA) priority pollutant [19] and proposed to be included in the list of priority substances of the European Union [20], with regulatory agencies imposing discharge limits in the order of $<1 \mathrm{ppm}[16,21]$.

Although several physical and chemical methods for cyanide remediation have been reported in the literature [16,21], the electro-oxidation technology gathers several benefits [14]. Basically, it can be conveniently operated in situ, at ambient temperature and pressure, with low energy consumption and short time requirements, just by using electrons as the only reagent. Furthermore, it simultaneously allows the recovery of precious metals on the cathode $[14,16]$. Nevertheless, the efficiency and cost of the electro-oxidation treatments greatly relies on the choice of a suitable electrocatalyst (anode) [14,22]. 
Several electrodes including carbon materials [23-26], stainless steel [27], bare Pt and Ni [28,29], boron-doped diamond (BDD) [30], $\mathrm{CuO}[11]$, and Ti-supported metal and metal oxide systems (the so-called dimensionally stable anodes, DSA) like $\mathrm{PbO}_{2}[30,31]$, $\mathrm{Pt}[28,32], \mathrm{RuO}_{2^{-}}$ $\mathrm{TiO}_{2}$ and $\mathrm{TaO}_{2}-\mathrm{IrO}_{2}$ [33], $\mathrm{SnO}_{2}-\mathrm{SbO}_{\mathrm{x}}[34,35], \mathrm{Co}_{3} \mathrm{O}_{4}$ [36,37], etc. were previously studied for the direct and indirect electrochemical oxidation of cyanide. However, the reported electrolytic processes by using these anodes showed slow oxidation rates and poor current efficiencies.

Various studies revealed an enhanced cyanide electro-oxidation in the presence of copper. This enhancement was assigned to an electrocatalytic effect caused by copper oxide films in-situ deposited on the anode [23-28,31,32]. This catalytic activity is in agreement with the reported promotion of cyanide decomposition by copper species when using other elimination methods [38,39]. Nevertheless, the electrodeposited copper oxide films showed variable low stability and adherence [11,24,31,32], hindering their practical application for electrochemical cyanide destruction.

The design of novel $\mathrm{Cu}$-based electrocatalysts is then receiving increasing attention. Both the catalytic and stability properties of the active copper phase can be greatly influenced by their chemical environment and/or the nature of the support [1-5]. We previously reported the preparation and properties of Ti-supported copper-doped cobalt oxide $\left(\mathrm{Cu}_{\mathrm{x}} \mathrm{Co}_{3-\mathrm{x}} \mathrm{O}_{4}\right)$ electrodes [40,41]. It was found that $\mathrm{Cu}$ (II) is effectively incorporated into the spinel lattice to form a solid solution (monophasic $\mathrm{Cu}-\mathrm{Co}$ spinel oxide) when the copper content does not exceed that for the stoichiometric $\mathrm{CuCo}_{2} \mathrm{O}_{4}$ spinel $(\mathrm{x}=1.0)$. Nevertheless, a new $\mathrm{CuO}$ phase segregates on the surface of oversaturated spinels $(\mathrm{x}=1.5)$. On the other hand, the $\mathrm{Cu}$-doping produces a catalytic effect for the oxygen evolution reaction (OER) in alkaline aqueous electrolyte. This good activity for the OER is expected to be detrimental for the efficiency of the anodic treatment of pollutants [14]. 
In this work, the electrocatalytic performance of $\mathrm{Ti}^{2} / \mathrm{Cu}_{\mathrm{x}} \mathrm{Co}_{3-\mathrm{x}} \mathrm{O}_{4}$ electrodes (with $0 \leq \mathrm{x} \leq 1.5$ ) for the oxidation of $\mathrm{CN}^{-}$is studied in an alkaline medium. This is the medium of choice because of the strongly basic character of cyanide-containing effluent streams from important industrial processes like silver and gold ore extraction, metallurgical processes or electroplating. In addition, a high alkalinity has been proven to obtain better oxidation efficiency [35] and favour the oxidation pathway towards cyanate and subsequent complete mineralization to $\mathrm{N}_{2}$ and $\mathrm{CO}_{2}$ [27,35]. The electrochemical behaviour of $\mathrm{CN}^{-}$onto these electrodes is followed by cyclic voltammetry and in-situ Raman spectroscopy, whereas its abatement is studied by galvanostatic electrolysis. The electroactivity of the electrodes is then analysed in terms of current efficiency and kinetics for $\mathrm{CN}^{-}$electro-oxidation. Results reveal that the introduction of $\mathrm{Cu}$ in the cobalt spinel remarkably increases the efficiency and kinetics for $\mathrm{CN}^{-}$electro-oxidation. Moreover, they suggest that this electrocatalytic effect is related to the specific adsorption and oxidation of $\mathrm{CN}^{-}$ions on surface $\mathrm{Cu}(\mathrm{II})$ placed in the spinel crystalline structure.

\section{Experimental}

\subsection{Preparation and physico-chemical characterization of $\mathrm{Cu}_{\mathrm{x}} \mathrm{Co}_{3-\mathrm{x}} \mathrm{O}_{4}$ electrodes.}

Copper-cobalt spinel oxide electrodes of nominal composition $\mathrm{Cu}_{\mathrm{x}} \mathrm{Co}_{3-\mathrm{x}} \mathrm{O}_{4}$ (with $0.0<\mathrm{x} \leq 1.5$ ) were prepared by thermal decomposition of proper salt precursors onto a Ti support [40]. The salt precursors were made up of $\mathrm{Co}\left(\mathrm{NO}_{3}\right)_{2} \cdot 6 \mathrm{H}_{2} \mathrm{O}$ (A.C.S Aldrich) and $\mathrm{Cu}\left(\mathrm{NO}_{3}\right)_{2} \cdot 3 \mathrm{H}_{2} \mathrm{O}(\mathrm{MERCK}$ p.a.) dissolved in absolute ethanol (J.T Baker). The nitrate salts were mixed in stoichiometric amounts according to the desired nominal composition. The total metallic cation concentration was kept constant at $0.5 \mathrm{M}$. Prior to the decomposition process, Ti plates $(1 \times 1 \times 0.05 \mathrm{~cm}$, Goodfellow 99.6\%) were degreased in acetone, etched in a boiling $10 \%$ oxalic acid solution for $1 \mathrm{~h}$ and finally rinsed with distilled water. The precursor solution was spread over the Ti surface with the aid of a brush. The solvent was dried at $70{ }^{\circ} \mathrm{C}$ and the electrode was subsequently 
calcined at $350{ }^{\circ} \mathrm{C}$ for $10 \mathrm{~min}$, for the thermal decomposition of the salt and metal oxide formation to be accomplished. The Ti sheets were coated with successive layers of the oxides by repeating this procedure. A final annealing step was carried out for $1 \mathrm{~h}$ at the same temperature. The most suitable number of deposition steps (about 23) was found to correspond to an oxide loading ranging between 3.00 and $3.50 \mathrm{mg} \mathrm{cm}^{-2}$, as determined by weight difference. For comparison purposes, Ti-supported $\mathrm{Co}_{3} \mathrm{O}_{4}$ and $\mathrm{CuO}$ electrodes were also prepared by the same method. The physicochemical properties of the electrodes were analyzed in detail in a previous paper [40]. In particular, it should be emphasized that the actual metal cation compostion is rather close to the nominal one used in this work to refer to the subscript $\mathrm{x}$ (see the supporting information (Supp. Info.)).

\subsection{Electrochemical behavior towards $\mathrm{CN}^{-}$oxidation}

\subsubsection{Cyclic voltammetry}

Electrochemical measurements were carried out at room temperature in a conventional threeelectrode cell. The counter electrode was a platinum electrode and the potentials are referred to a reversible hydrogen electrode (RHE) immersed in the same electrolyte. The aqueous $0.1 \mathrm{M}$ $\mathrm{NaOH}$ solutions were prepared from Merck p.a. and ultrapure water (Purelab Ultra from ElgaVivendi, 18.2 $\mathrm{M} \Omega \mathrm{cm}$ ), whereas sodium cyanide (Merck p.a.) was used to simulate the $\mathrm{CN}^{-}$containing waters of different concentrations. The alkalinity of the electrolyte solution $(\mathrm{pH}=13)$ was high enough to avoid the formation and volatilization of $\mathrm{HCN}(\mathrm{pKa}=9.21)$.

The cyclic voltammograms were obtained at a constant sweep rate of $20 \mathrm{mV} \mathrm{s}^{-1}$. The current densities were calculated using the geometric area of the electrodes $\left(2 \mathrm{~cm}^{2}\right)$.

\subsubsection{Electrolysis runs}


Cyanide electro-oxidation experiments were performed galvanostatically in a filter-press cell. Copper-doped cobalt oxides, deposited on titanium expanded meshes (electrode area $20 \mathrm{~cm}^{2}$ ), were used as anodes, whereas a stainless steel plate (AISI 310L) electrode of $20 \mathrm{~cm}^{2}$ was used as the cathode. The starting concentration of cyanide was $500 \mathrm{ppm}$ and an aqueous $0.1 \mathrm{M} \mathrm{NaOH}$ solution was employed as the supporting electrolyte. The electrolyte was introduced in a jacketed reservoir and was forced to pass through the undivided cell by means of a centrifugal pump (flow rate $=40.6 \mathrm{~mL} \mathrm{~s}^{-1}$ ). Details on the experimental determination of the mass transfer coefficient $\left(k_{m}\right)$ are provided in the supporting information (Supp. Info.). The electrolyte volume was $500 \mathrm{~cm}^{3}$ and the temperature was controlled at $25^{\circ} \mathrm{C}$ during the experiment. The applied constant current density was $5 \mathrm{~mA} \mathrm{~cm}^{-2}$ in all experiments. During the constant-current electrolyses, the cyanide concentration was measured by titration with a $\mathrm{AgNO}_{3}$ standard solution (0.1875 $\mathrm{mM})$ using 5-(4-dimethylaminobencylidene)-rhodanine as indicator (EPA, 4500-CN-D) [42] and an $\mathrm{Ag} / \mathrm{AgCl} / \mathrm{Cl}^{-}(3 \mathrm{M})$ electrode was used as a reference electrode to monitor the anode potential. The reported cyanide concentration data represent the arithmetic average from three measurements and the current efficiency for the cyanide oxidation was calculated from the decrement of the cyanide concentration in the test solution.

\subsubsection{In-situ Raman spectroscopy characterization}

The electroxidation of $\mathrm{CN}^{-}$on $\mathrm{Cu}_{\mathrm{x}} \mathrm{Co}_{3-\mathrm{x}} \mathrm{O}_{4}$ electrodes was monitored by in-situ Raman spectroscopy. The experiments were performed in a three-electrode spectro-electrochemical cell made of polytetrafluoroethylene (PTFE). More details on this cell can be found in reference [43]. A platinum wire was used as the counter-electrode, whereas a saturated calomel electrode (SCE) was used as the reference electrode contacting the working solution through a Luggin capillary. Nevertheless, the potentials were referred to the reversible hydrogen electrode (RHE) $\left(\mathrm{E}_{\mathrm{RHE}}=\right.$ 
$\left.\mathrm{E}_{\mathrm{SCE}}+1.011 \mathrm{~V}\right)$. The electrolytic solution was a $0.1 \mathrm{M} \mathrm{NaOH}$ solution containing $5000 \mathrm{ppm} \mathrm{CN}^{-}$ (192.2 mM NaCN).

Among the different anode compositions, only $\mathrm{Co}_{3} \mathrm{O}_{4}, \mathrm{Cu}_{0.8} \mathrm{Co}_{2.2} \mathrm{O}_{4}$ and $\mathrm{Cu}_{0.5} \mathrm{Cu}_{1.0} \mathrm{Co}_{2.0} \mathrm{O}_{4}$ were chosen and used as working electrodes for this study. The oxide electrodes were prepared by thermal decomposition of the precursor salts, as described in section 2.1., but onto a disk of polycrystalline polished platinum or gold (only in the case of $\mathrm{x}=0.8$ ) of 2 and $3 \mathrm{~mm}$ in diameter, respectively. Thin oxide films were prepared by applying only 5 deposition steps, in order to achieve and compare surface enhanced Raman effects [44]. The Pt disk was pre-treated with boiling $10 \%$ oxalic acid solution, similarly to the case of Ti plates and meshes. The Au disk, however, was previously submitted to an electrochemical Oxidation-Reduction Cycle (ORC) treatment to cause surface roughening, a well-known necessary requirement for large surface enhanced Raman signals [44]. This roughening procedure is the most important method to prepare SERS-active surfaces [44]. Particularly, the performed roughening consisted of 25 ORC cycles in $0.1 \mathrm{M} \mathrm{KCl}$, each cycle involving the following steps [44]: 1) constant reduction potential at $-0.3 \mathrm{~V}$ for $30 \mathrm{~s} ; 2$ ) linear sweep potential from $-0.3 \mathrm{~V}$ to $1.2 \mathrm{~V}$ at $1 \mathrm{~V} \mathrm{~s}^{-1}$; 3) constant oxidation potential at $1.2 \mathrm{~V}$ for $1.2 \mathrm{~s}$; 4) linear sweep potential from $1.2 \mathrm{~V}$ to $-0.3 \mathrm{~V}$ at $0.5 \mathrm{~V} \mathrm{~s}^{-1}$; 5) constant reduction potential at $-0.3 \mathrm{~V}$ for $30 \mathrm{~s}$. This treatment was separately carried out by using the same experimental setup as in the case of cyclic voltammetry (section 2.2.1). After the deposition of metal oxides, the disks were sheathed in a threaded PTFE piece and mounted on the electrochemical PTFE cell.

The Raman spectra were obtained with a LabRam spectrometer (from Jobin-Yvon Horiba) coupled to an upright confocal microscope Olympus BX30. The excitation line was provided by a $9 \mathrm{~mW}$ He-Ne laser at $632.8 \mathrm{~nm}$. The calibration of the spectrometer was performed with a Si slice $\left(521 \pm 2 \mathrm{~cm}^{-1}\right)$. The laser beam was focused through a $50 \times$ long-working objective $(0.5$ NA) into a $2 \mu \mathrm{m}$ spot at the electrode surface. The sample viewing system consisted of a 
television camera attached to the microscope. The spectrometer resolution was better than $3 \mathrm{~cm}^{-1}$ and the detector was a Peltier cooled charge-couple device $(\mathrm{CCD})(1064 \times 256$ pixels $)$. The used pinhole and slit were set at $600 \mu \mathrm{m}$ and $200 \mu \mathrm{m}$, respectively. The acquisition time of spectra was $180 \mathrm{~s}$ and 3 averages were performed. In order to ensure reproducibility of the analysis, two electrodes were prepared and analyzed for each oxide composition.

\section{Results and Discussion}

\subsection{Cyclic voltammetry}

Figure 1 shows the stabilized cyclic voltammograms of $\mathrm{Ti} / \mathrm{Cu}_{\mathrm{x}} \mathrm{Co}_{3-\mathrm{x}} \mathrm{O}_{4}$ electrodes in the absence $(0 \mathrm{ppm})$ or presence $(100$ or $500 \mathrm{ppm})$ of $\mathrm{CN}^{-}$. In the case of $\mathrm{CN}$-free electrolyte, the $\mathrm{Ti} / \mathrm{Co}_{3} \mathrm{O}_{4}$ electrode (Figure 1a) shows two characteristic redox peaks at a half-wave potential of $1.20 \mathrm{~V}\left(\mathrm{~A}_{1} / \mathrm{C}_{1}\right)$ and $1.48 \mathrm{~V}\left(\mathrm{~A}_{2} / \mathrm{C}_{2}\right)$, which have been previously assigned to $\mathrm{Co}$ (II) $\leftrightarrow \mathrm{Co}$ (III) and $\mathrm{Co}(\mathrm{III}) \leftrightarrow \mathrm{Co}(\mathrm{IV})$ surface transitions, respectively $[37,40]$. The sharp current rise occurring at potentials above the $A_{2}$ peak corresponds to the oxygen evolution reaction (OER). As copper is incorporated into the cobalt spinel lattice $(0.0<\mathrm{x} \leq 1.0)$ (Figures $1 \mathrm{~b}-\mathrm{e}, 0 \mathrm{ppm} \mathrm{CN}^{-}$) the first redox couple $\left(\mathrm{A}_{1} / \mathrm{C}_{1}\right)$ progressively vanishes and both the second transition and the OER shift to less positive potentials. This was associated with an electrocatalytic effect in the OER by the presence of copper in the electrode [40] (see also the Tafel plots in the Supp. Info.). For a copper

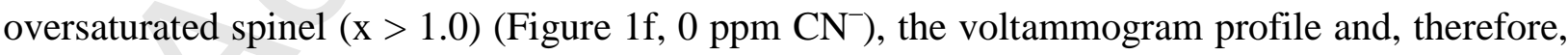
the electrochemical behavior drastically change to that of a CuO-like surface phase [40].

In the presence of $\mathrm{CN}^{-}$, the $\mathrm{Ti} / \mathrm{Cu}_{\mathrm{x}} \mathrm{Co}_{3-\mathrm{x}} \mathrm{O}_{4}$ electrodes with small $\mathrm{Cu}$ contents $(\mathrm{x} \leq 0.5)$ showed, a slight increase in the anodic current of the $\mathrm{A}_{2}$ wave during the first forward scan (cycle not shown). This current has been attributed to the indirect electro-oxidation of cyanide by highly powerful oxidant $\mathrm{Co}(\mathrm{IV})$ surface species generated in this potential region [36,37]. During the following cycles (Fig. 1a-c), both the anodic and cathodic currents in the $\mathrm{A}_{2} / \mathrm{C}_{2}$ potential region 
progressively decayed below the values for the stabilized voltammogram in the background electrolyte $\left(0 \mathrm{ppm} \mathrm{CN}^{-}\right)$, and this decay gradually augmented with the $\mathrm{CN}^{-}$concentration. This behaviour seems to imply the blockage of the electroactive surface by an inhibiting product from cyanide oxidation [37].
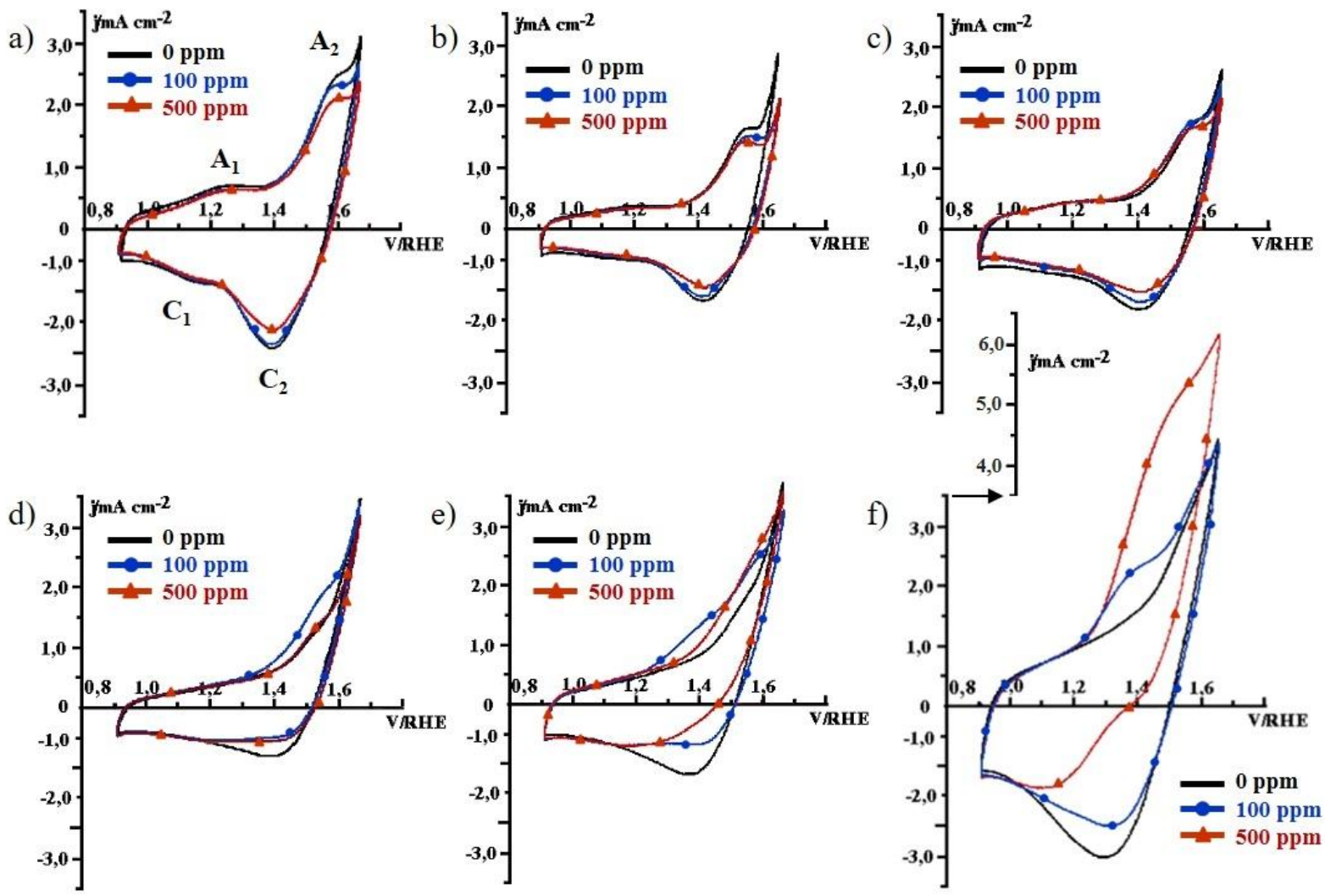

Figure 1. Stabilized cyclic voltammograms (10th cycle) of the $\mathrm{Ti} / \mathrm{Cu}_{\mathrm{x}} \mathrm{Co}_{3-\mathrm{x}} \mathrm{O}_{4}$ electrodes in 0.1 $\mathrm{M} \mathrm{NaOH}$ and 0, 100, 500 ppm $\mathrm{CN}^{-}$solutions: $\mathrm{x}=0.0$ (a); 0.2 (b); 0.5 (c); 0.8 (d); 1.0 (e); 1.5 (f). Scan rate $=20 \mathrm{mV} \mathrm{s}^{-1}$.

By contrast, at greater amounts of $\mathrm{Cu}$ in the spinel $(\mathrm{x}=0.8$ and 1.0) (Fig. 1d and 1e), a clear change in the electrochemical behavior of the electrodes occurs: (i) the onset of $\mathrm{CN}^{-}$electrooxidation shifts towards lower potentials; (ii) the $\mathrm{CN}^{-}$oxidation current in the potential region of the $A_{2}$ wave is still observed (above the blank voltammogram) even after 10 cycles (when the steady state is achieved); and (iii) the cathodic $\mathrm{C}_{2}$ peak practically disappears, suggesting again the participation of highly oxidant surface species in the mediated electro-oxidation of $\mathrm{CN}^{-}$. The oversaturated spinel electrode ( $\mathrm{x}>1.0)$ (Fig. 1f) clearly confirmed this electrochemical behavior. 
On the other hand, for a given electrode with any of these compositions (Fig. 1d-f) it is observed that an increase in cyanide concentration is accompanied with an increase in the oxidation current of $\mathrm{A}_{2}$ wave and a decrease in the reduction current of $\mathrm{C}_{2}$ peak. Similarly, for a given cyanide concentration, the oxidation current associated to $A_{2}$ peak increases with the $\mathrm{Cu}$ content in the spinel. All these results indicate that the presence of $\mathrm{Cu}$ in the Co-spinel electrodes enhances their activity towards $\mathrm{CN}^{-}$electro-oxidation.

\subsection{Electrolysis performance and electro-oxidation kinetics}

Figure 2 shows the evolution of the normalized cyanide concentration $\left(C / C_{0}\right)$ with the electrolysis time and the ratio of relative charge $\left(Q / Q_{t h}\right)$ passed during the electrolysis by using cobalt oxide electrodes doped with different copper content (x). In the figure, $C$ and $Q$ correspond to the cyanide concentration and the passed charge, respectively, at a given time; whereas $C_{0}$ refers to the initial cyanide concentration $(500 \mathrm{ppm})$ and $Q_{t h}$ refers to the theoretical charge necessary for the complete removal of cyanide by direct oxidation to cyanate according to the following reaction $[23,27]$ :

$$
\mathrm{CN}^{-}+2 \mathrm{OH}^{-} \rightarrow \mathrm{OCN}^{-}+\mathrm{H}_{2} \mathrm{O}+2 e^{-}
$$

As shown in Figure 2, the $\mathrm{Co}_{3} \mathrm{O}_{4}$ anode is able to oxidize only a $4 \%$ of initial cyanide after 10 $\mathrm{h}$ of electrolysis, thus, displaying practically no activity for cyanide oxidation at the studied conditions. The introduction of small amounts of copper in the spinel $(\mathrm{x} \leq 0.5)$ slightly increases the performance, but the electrodes cannot oxidize more than $30 \%$ of initial cyanide in the first 5 $\mathrm{h}$ of treatment. In the case of $\mathrm{x}=0.5$, around $55 \%$ of cyanide can be eliminated after $10 \mathrm{~h}$ treatment. However, when the copper content in the oxide layer is higher than 0.5 , the amount of cyanide in the solution during the electrolysis drastically decreases with time. It has to be stressed that when the amount of copper reaches or overcomes that of the saturation of the spinel structure $(\mathrm{x}=1.0$ or 1.5$)$, the initial cyanide concentration can be reduced to less than $50 \mathrm{ppm}$ in 
$5 \mathrm{~h}$. Moreover, these anodes can successfully eliminate cyanide to concentrations below $1 \mathrm{ppm}$ (regulatory limits) in only $7 \mathrm{~h}$.

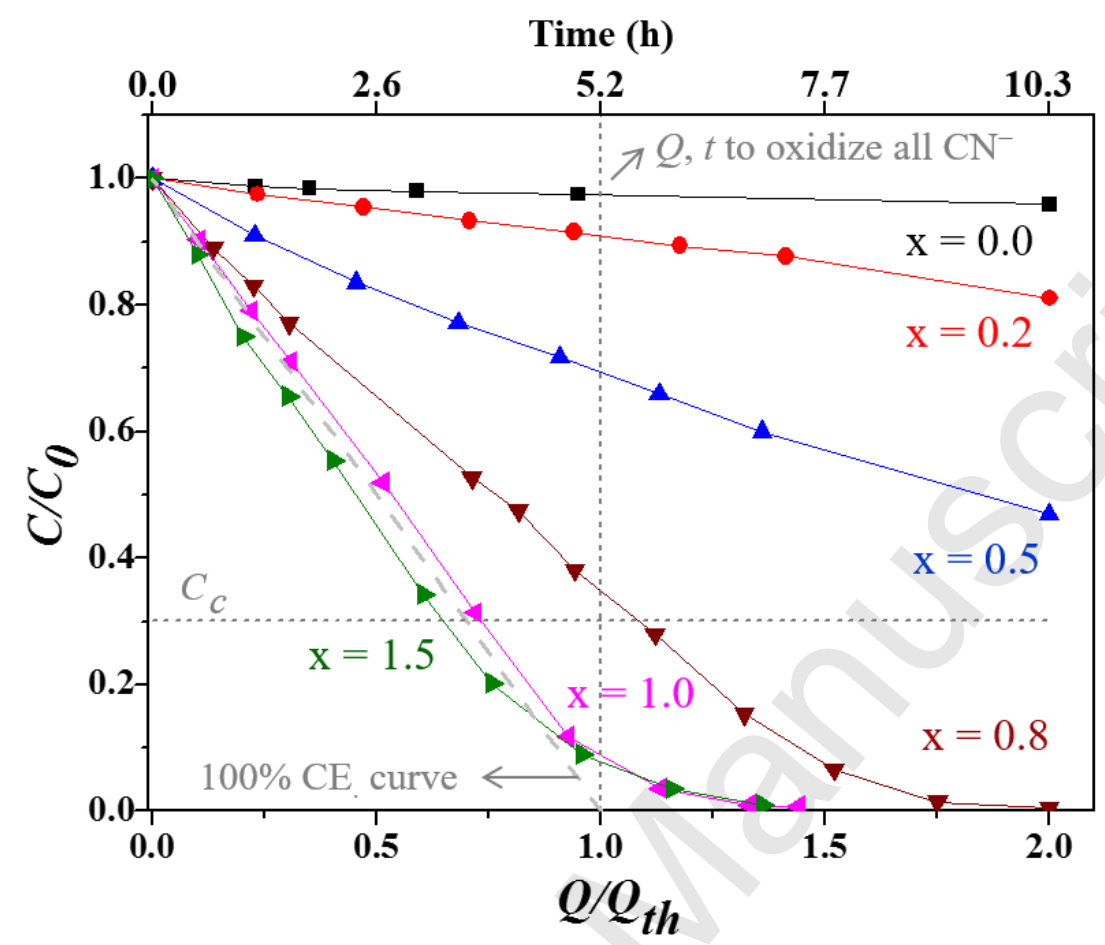

Figure 2. Evolution of the normalized cyanide concentration with time and the ratio of relative charge passed during electrolysis at $5 \mathrm{~mA} \mathrm{~cm}{ }^{-2}$ by using $\mathrm{Ti} / \mathrm{Cu}_{\mathrm{x}} \mathrm{Co}_{3-\mathrm{x}} \mathrm{O}_{4}$ electrodes in $0.1 \mathrm{M}$ $\mathrm{NaOH}+500$ ppm $\mathrm{CN}^{-}$solution.

The representation of the normalized cyanide concentration as a function of the electrolysis time makes it easier to interpret the kinetics and provides a straight picture of the process timescale, helpful to the eventual scaling-up of electrolytic remediation of cyanide-containing effluent streams by using $\mathrm{Ti} / \mathrm{Cu}_{\mathrm{x}} \mathrm{Co}_{3-\mathrm{x}} \mathrm{O}_{4}$ as anode catalysts. The concentration decay follows two well-defined regimes, namely, a linear decrease (Region I) to a certain transition or critical time or cyanide conversion from which the time dependence becomes exponential (Region II). The linear regime is characteristic of a pseudo zero-order kinetics in which the electro-oxidation is current-limited, i.e. when $j_{a p p}$ (applied current) $<j_{\text {lim }}$ (limiting current density); whereas the exponential decay follows a pseudo first-order kinetics and mass-transport control, at which $j_{a p p}$ $>j_{\text {lim. }}$. Thus, during the electrolysis treatment, the limiting current density falls with the cyanide 
concentration until it becomes equal to the applied current $\left(j_{a p p}=j_{\text {lim }}\right)$, moment at which the transition from a charge-transfer regime to a diffusion regime occurs. The concentration of cyanide at this regime transition is called critical concentration, $C_{C}$.

Under pseudo zero-order kinetics, the following linear rate law applies:

$$
\frac{C}{C_{0}}=1-\frac{k_{0}}{C_{0}} t
$$

where $C$ and $C_{0}$ stand for cyanide concentration $\left(\mathrm{mol} \mathrm{m}^{-3}\right)$ at time $t(\mathrm{~s})$ and the initial cyanide concentration (in $\mathrm{mol} \mathrm{m}{ }^{-3}$ ), respectively. On the other hand, $k_{0}$ is the zero-order rate constant $\left(\mathrm{mol} \mathrm{m} \mathrm{m}^{-3} \mathrm{~s}^{-1}\right)$ for cyanide electro-oxidation, which relates to electrolysis parameters as follows:

$$
k_{0}=C E_{0} \frac{j_{a p p} A}{z F V}
$$

where $j_{a p p}$ is the applied current density $\left(\mathrm{A} \mathrm{m}^{-2}\right), A$ is the electrode surface area $\left(\mathrm{m}^{2}\right), V$ is the electrolyte volume $\left(\mathrm{m}^{3}\right), F$ is the Faraday constant $\left(96485 \mathrm{C} \mathrm{mol}^{-1}\right), z$ is the number of electrons involved in the oxidation process and $C E_{0}$ is the constant zero-order current efficiency for cyanide oxidation.

Note that the term $j_{\text {app }} A t$ in the zero-order rate law (Eq. 2) corresponds to the amount of charge passed at time $t$, and the product $z F V C_{0}$ equals the charge necessary for the complete removal of the pollutant in a z-electron process. Then, the zero-order expression (Eq. 2) can be conveniently written as a function of the relative charge as:

$$
\frac{C}{C_{0}}=1-C E_{0} \frac{Q}{Q_{t h}}
$$

Consequently, the slope of the linear portion of a $\mathrm{C} / \mathrm{C}_{0}$ vs. $\mathrm{Q} / \mathrm{Q}_{\text {th }}$ graph (Fig. 2) directly provides the value of $C E_{0}$ for the electrochemical process. In this kind of representation, the ratio $Q / Q_{t h}=1$ denotes that the necessary charge has passed to theoretically electro-oxidize all the cyanide according to reaction (1)

On the other hand, the zero-order rate constant $\left(k_{0}\right)$ for cyanide electro-oxidation can be simply calculated from the $C E_{0}$ values, according to Eq. 3. Note that both parameters are directly related 
to each other and, since they are inherent to the charge-transfer regime, they can be taken indistinctly as an account of the electrocatalytic activity of the different anodes.

In order to help in a reliable determination of efficiencies and rate constants from fitting of experimental data in Fig. 2, the boundary between zero- and first-order kinetic regimes was conveniently established by the estimation of the critical concentration to the initial concentration ratio. At the critical concentration the limiting current density equals the applied current density:

$$
j_{a p p}=k_{m} z F C_{c}
$$

Whereas the limiting current density reaches its highest value at the initial concentration $\left(C_{0}=\right.$ $19.216 \mathrm{~mol} \mathrm{~m}^{-3}$ ) according to:

$$
j_{\text {lim }}^{0}=k_{m} z F C_{0}
$$

where $k_{m}$ is the mass transfer coefficient $\left(4.48 \times 10^{-5} \mathrm{~m} \mathrm{~s}^{-1}\right.$, see Supp. Info.); $z$ is the number of electrons ( 2 electrons, from Eq. 1$) ; A$ is the geometric area of the electrode $\left(2 \times 10^{-3} \mathrm{~m}^{2}\right)$; and $F$ is the Faraday constant $\left(96485 \mathrm{~F} \mathrm{~mol}^{-1}\right)$. This calculation gives $j^{0}{ }_{l i m}=16.6 \mathrm{~mA} / \mathrm{cm}^{2}$.

Next, dividing eq. 5 by eq. 6 simply gives the required ratio $C_{C} / C_{0}=0.3012$ (horizontal dotted line in Fig, 2). Hence, at concentrations below this value the electrolysis shows mass diffusion problems, related to the lack of availability of cyanide ions at the electrode surface, and the oxygen evolution reaction (OER) occurs instead as a parallel side-reaction:

$$
4 \mathrm{OH}^{-} \rightarrow \mathrm{O}_{2}+2 \mathrm{H}_{2} \mathrm{O}+4 e^{-}
$$

Table 1 collects the values of $C E_{0}$ and $k_{0}$ calculated for the different electrode compositions. We used data points above $C_{C} / C_{0}=0.3012$ for the linear fits in Fig. 2 and the retrieval of the corresponding zero-order parameters. As can be observed, the copper-free $\mathrm{Co}_{3} \mathrm{O}_{4}$ anode shows low values of $C E_{0}$ and $k_{0}$ for cyanide oxidation. By contrast, the gradual substitution of Co by $\mathrm{Cu}$ in the $\mathrm{Cu}_{\mathrm{x}} \mathrm{Co}_{3-\mathrm{x}} \mathrm{O}_{4}$ anodes results in a rapid increase in both parameters up to $\mathrm{x}=1.0$, and then, it tends to slowly increase above the spinel saturation. Close to saturation and beyond, the 
spinels exhibit rate constants of around two orders of magnitude higher than $\mathrm{Co}_{3} \mathrm{O}_{4}$, as well as efficiencies close to $100 \%$. Such an excellent efficiency of the saturated and oversaturated spinels can be clearly followed from Fig. 2, which show experimental concentration decays that practically coincide with a theoretically predicted $100 \%$ current efficiency response (dashed line in Fig. 2).

Figure 3 depicts the evolution of $C E_{0}$ and $k_{0}$ as a function of the copper content in the cobalt spinel. The observed sinusoidal-like evolution of the current efficiency and kinetics for cyanide electro-oxidation upon spinel modification points out an outstanding electrocatalytic effect of $\mathrm{Cu}$ on the performance of the cobalt spinel electrode. Considering that the oversaturated spinel $(\mathrm{x}=$ 1.5) behaves electrochemically like $\mathrm{CuO}$ (Fig. 1f), it can be inferred that the saturated spinel $(\mathrm{x}=$ $1 ; \mathrm{CuCo}_{2} \mathrm{O}_{4}$ ) shows quite similar electrocatalytic activity to that of $\mathrm{CuO}$.

Table 1. Current efficiencies $\left(C E_{0}\right)$ and pseudo-zero order rate constants $\left(k_{0}\right)$ for $\mathrm{CN}^{-}$electrooxidation calculated at $C / C_{0}<0.301$ (in the charge-transfer region of Fig. 2); and service life of the different $\mathrm{Ti} / \mathrm{Cu}_{\mathrm{x}} \mathrm{Co}_{3-\mathrm{x}} \mathrm{O}_{4}$ electrodes.

\begin{tabular}{|c|c|c|c|}
\hline $\begin{array}{c}\text { Electrode } \\
\mathrm{Ti} / \mathrm{Cu}_{\mathrm{x}} \mathrm{Co}_{3-\mathrm{x}} \mathrm{O}_{4} \\
(\mathrm{x})\end{array}$ & $\begin{array}{c}\text { Current efficiency } \\
\left(C E_{0}\right) \\
(\%)\end{array}$ & $\begin{array}{c}\text { Zero-order rate } \\
\text { constant }(k 0) \\
\left(\mathrm{x} 10^{-4} \mathrm{~mol} \mathrm{~m}^{-3} \mathrm{~s}^{-1}\right)\end{array}$ & $\begin{array}{c}\text { Service life [40] } \\
\left(\mathrm{A} \mathrm{h} \mathrm{mg}^{-1}\right)\end{array}$ \\
\hline 0.0 & 1.5 & 0.16 & 184 \\
\hline 0.2 & 9.1 & 0.95 & 160 \\
\hline 0.5 & 26.1 & 2.71 & 122 \\
\hline 0.8 & 63.4 & 6.57 & 114 \\
\hline 1.0 & 94.7 & 9.82 & 119 \\
\hline 1.5 & 99.9 & 11.15 & 150 \\
\hline
\end{tabular}




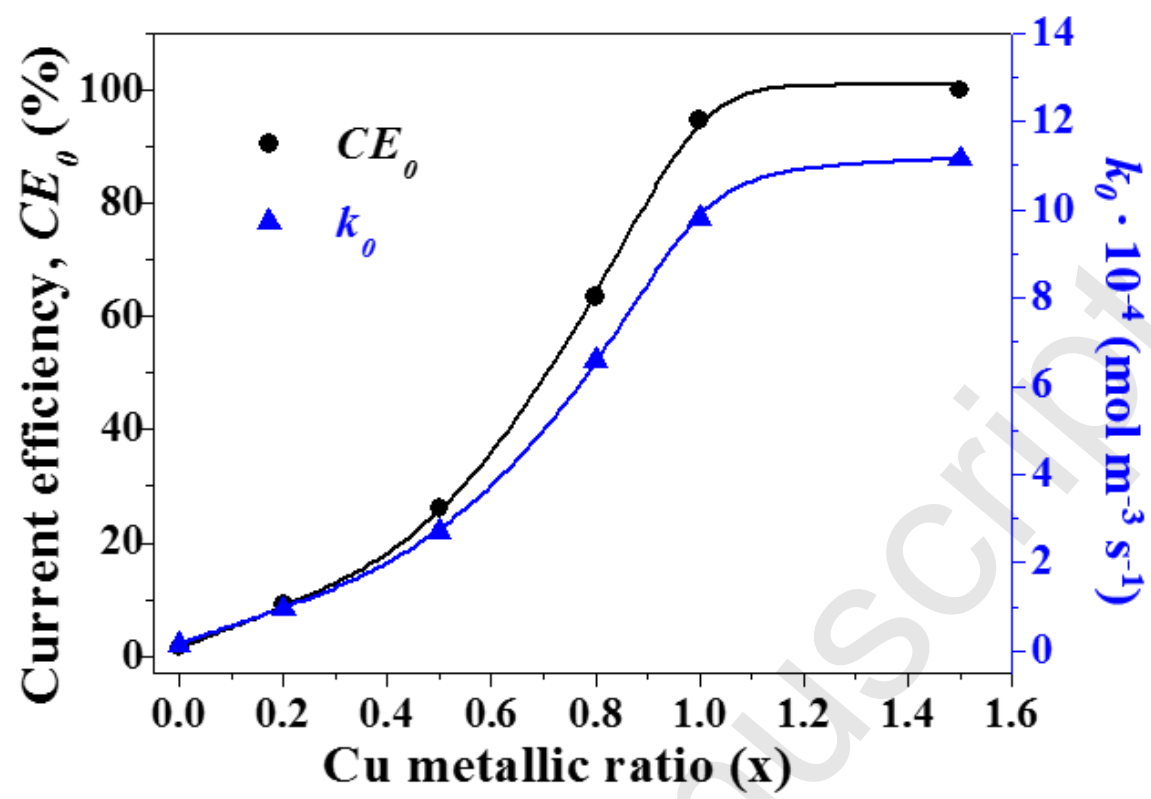

Figure 3. Influence of the $\mathrm{Cu}$ metallic ratio composition on the zero order current efficiency $\left(C E_{0}\right)$ and rate constant $\left(k_{0}\right)$ for cyanide electro-oxidation on $\mathrm{Ti} / \mathrm{Cu}_{\mathrm{x}} \mathrm{Co}_{3-\mathrm{x}} \mathrm{O}_{4}$ electrodes $(0.1 \mathrm{M}$ $\mathrm{NaOH}+500$ ppm $\mathrm{CN}^{-}$solution).

The transition from charge-transfer to diffusion regime during electrolysis of cyanide on $\mathrm{Cu}_{\mathrm{x}} \mathrm{Co}_{3-\mathrm{x}} \mathrm{O}_{4}$ anodes has been also observed during the treatment of organic pollutants with other electrodes [22]. However, all the reported studies on cyanide electro-oxidation describe exclusively pseudo first-order kinetics for the different anodes and conditions employed [26,30,33.34,36]. Accordingly, the obtained zero-order rate constants for cyanide electrooxidation on $\mathrm{Cu}_{\mathrm{x}} \mathrm{Co}_{3-\mathrm{x}} \mathrm{O}_{4}$ anodes cannot be directly compared with the kinetics of previously studied anode materials. Nonetheless, it can be inferred that the highest rate constants obtained in this work for the saturated and oversaturated spinels, of about $1 \times 10^{-3} \mathrm{~mol} \mathrm{~m}^{-3} \mathrm{~s}^{-1}$, are in the order of the fastest initial rates of the reported mass-controlled $\mathrm{CN}^{-}$treatments with other electrodes

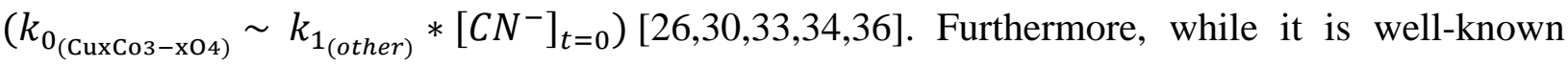
that the reaction rate generally increases with the applied current density [35], it is noteworthy to mention that these first-order rate constants $\left(k_{1}\right)$ of other anodes in literature were obtained by 
using comparatively larger current densities $\left(10-50 \mathrm{~mA} / \mathrm{cm}^{2}\right)[26,30,33,34,36]$. Consequently, our results show that saturated and oversaturated $\mathrm{Cu}$-Co spinel electrocatalysts enable complete cyanide conversion in an electrolytic process operated at low current density and high efficiency, at a fast and sustained (constant) rate, which is highly advantageous compared to previously reported first-order electrochemical oxidations, that exhibit typical rate decay as cyanide is consumed.

One should recall that the current efficiency and rate constants in Table 1 were obtained under the assumption that cyanide is oxidized to cyanate in a 2-electron step (eq. 1). It is well-known that cyanate can be subsequently mineralized in strongly alkaline medium as follows $[27,30]$ :

$$
\mathrm{OCN}^{-}+4 \mathrm{OH}^{-} \rightarrow \mathrm{CO}_{3}^{2-}+1 / 2 \mathrm{~N}_{2}+2 \mathrm{H}_{2} \mathrm{O}+3 e^{-}
$$

However. when $Q_{t h}$ was considered as the theoretical charge consumed for complete electrochemical combustion of cyanide in a five-electron process, physically meaningless current efficiencies (well above $150 \%$ ) were obtained for heavily $\mathrm{Cu}$-doped spinel anodes $(\mathrm{x} \geq 0.8)$. Therefore, our results consistently suggest that the oxidation practically proceeds towards cyanate formation according to Eq. 1, at least for the first $4 \mathrm{~h}$ of treatment (zero-order regime) under the studied conditions. This is in agreement with previous studies, which showed that the kinetics of cyanate decomposition (Eq. 8) is considerably slower, so it begins when cyanide has mostly reacted $[30,32,36]$. As a result, cyanate oxidation (Eq. 8) can be neglected under the zeroorder regime, validating the assumption made for $C E_{0}$ calculation.

A detailed analysis of intermediates and final products of cyanide electroxidation is not the aim of present work, but the formation of derived compounds must be considered for any potential application of $\mathrm{Ti} / \mathrm{Cu}_{\mathrm{x}} \mathrm{Co}_{3-\mathrm{x}} \mathrm{O}_{4}$ electrodes in the remediation of cyanidic wastewaters. In this sense, the produced cyanate is several hundred times less toxic than cyanide $[15,16,45]$. This compound can be further electroxidized by extending the electrolysis time and by using suitable conditions. Under highly alkaline conditions, cyanate can subsequently undergo electrochemical 
mineralization to carbonate and $\mathrm{N}_{2}$ as final products (reaction (8)) $[27,28,35]$. By contrast, if the alkalinity is not high enough, highly toxic cyanogen can be derived from the electro-oxidation of cyanide [23,28], whereas cyanate can chemically decompose to other by-products [27]. Previous studies have demonstrated that an initial $\mathrm{pH}$ of around 13, like that used in present work, is high enough to ensure the preferred elimination pathway via reactions (1) and (8) [27,28,35]. Hence, the efficient electro-oxidation of cyanide observed on $\mathrm{Ti} / \mathrm{Cu}_{\mathrm{x}} \mathrm{Co}_{3-\mathrm{x}} \mathrm{O}_{4}$ electrodes is considered an attractive decontamination route for $\mathrm{CN}^{-}$-containing wastewaters.

Under highly alkaline conditions, hydroxides are expected to actively participate in the OER (Eq. 7) to lower the overall current efficiency for cyanide oxidation. This may be one the main reasons to explain the low efficiencies previously obtained with other anodes [24-36]. For example, BDD [30] and non-active metal oxides [34] anodes showed quite low efficiencies $(<10$ $\%$ ), for cyanide electro-oxidation. These materials have been reported to be excellent electrocatalysts for electro-oxidize refractory organic matter [14], owing to the high overpotential for the OER and the high reactivity of their generated physisorbed hydroxyl radicals $\left({ }^{\circ} \mathrm{OHs}\right)_{\mathrm{ads}}$. However, $\left({ }^{\circ} \mathrm{OHs}\right)_{\mathrm{ads}}$ are probably not as active for cyanide oxidation as in the case of organic matter. On the contrary, the considerably higher current efficiencies (30-70\%) obtained by active metal oxides, like $\mathrm{Co}_{3} \mathrm{O}_{4}$ [36], $\mathrm{RuO}_{2}-\mathrm{TiO}_{2}$ [33] or $\mathrm{CuO}$ deposits [24,26], may indicate that $\mathrm{CN}^{-}$oxidation involving the participation of reversible redox couples may be more effective. The features observed in the cyclic voltammograms of cyanide on $\mathrm{Cu}_{\mathrm{x}} \mathrm{Co}_{3-\mathrm{x}} \mathrm{O}_{4}$ electrodes (Fig. 1) are consistent with a mechanism of mediated oxidation by surface redox couples, so explaining their high efficiency.

Even more outstanding, the $\mathrm{Cu}_{\mathrm{x}} \mathrm{Co}_{3-\mathrm{x}} \mathrm{O}_{4}$ electrodes not only behave as active oxides, but also their electrocatalytic activity for the OER was found to gradually increase with the $\mathrm{Cu}$ content [40]. This is in agreement also with other works, which reported a good performance of $\mathrm{CuCo}_{2} \mathrm{O}_{4}$ electrodes for the OER [46,47]. Thus, to the knowledge of the authors, it is the first 
time that an anode material showing these properties exhibits $100 \%$ current efficiency in the oxidation of cyanide, and therefore, maximum selectivity for its conversion in aqueous electrolyte.

\subsection{In situ Raman Spectroscopy study of $\mathrm{CN}^{-}$electro-oxidation}

The electrochemical behavior of cyanide on $\mathrm{Cu}_{\mathrm{x}} \mathrm{Co}_{3-\mathrm{x}} \mathrm{O}_{4}$ electrodes was studied by in situ Raman Spectroscopy at different potentials. Figure 4 displays the Raman spectra of $\mathrm{Co}_{3} \mathrm{O}_{4}$ and oversaturated $\mathrm{Cu}_{0.5} \mathrm{Cu}_{1.0} \mathrm{Co}_{2} \mathrm{O}_{4}$ electrodes at open circuit potential (OCE). In both cases, the spectra show clearly discernible bands located in two separated regions. The high intensity bands at the lower wavenumbers $\left(400-700 \mathrm{~cm}^{-1}\right)$ are characteristic of the metal oxide, whereas the region at the higher wavenumbers $\left(2000-2200 \mathrm{~cm}^{-1}\right)$ presents the spectral features related to cyanide species.

In the case of $\mathrm{Co}_{3} \mathrm{O}_{4}$ (Fig. 4a), the spectrum shows four bands at 482, 523, 620 and $689 \mathrm{~cm}^{-1}$, which are characteristic of different vibration modes $\left(E_{g}\right.$, two $F_{2 g}$ modes and $A_{1 g}$, respectively) of $\mathrm{Co}^{+2}-\mathrm{O}$ and $\mathrm{Co}^{+3}-\mathrm{O}$ bonds in the cobalt spinel structure with F3dm space group symmetry [48] The features of these bands were not affected by the applied electrode potential (see Supp. Info). The Raman spectrum also presents a characteristic band at $2080-2082 \mathrm{~cm}^{-1}$. Neither the position nor the relative intensity of this band were significantly affected upon changing the electrode potential, at least in the range OCE - $1.65 \mathrm{~V}$ (inset of Fig. 4a); and the same behavior was observed independently of the nature of the electrode (see below). Therefore, the band at $2080 \mathrm{~cm}^{-1}$ is assigned to free cyanide in solution close to the electrode surface [49]. Note that the absence of Raman features with frequencies in the order of adsorbed or in-solution $\left[\mathrm{Co}(\mathrm{CN})_{\mathrm{n}}\right]^{-}$ complexes, reported at $2100-2110$ or $2140-2150 \mathrm{~cm}^{-1}$, respectively $[49,50]$, could suggest the lack of any specific interaction between $\mathrm{Co}^{2+}$ and $\mathrm{Co}^{3+}$ species in the spinel lattice with cyanide ions. 

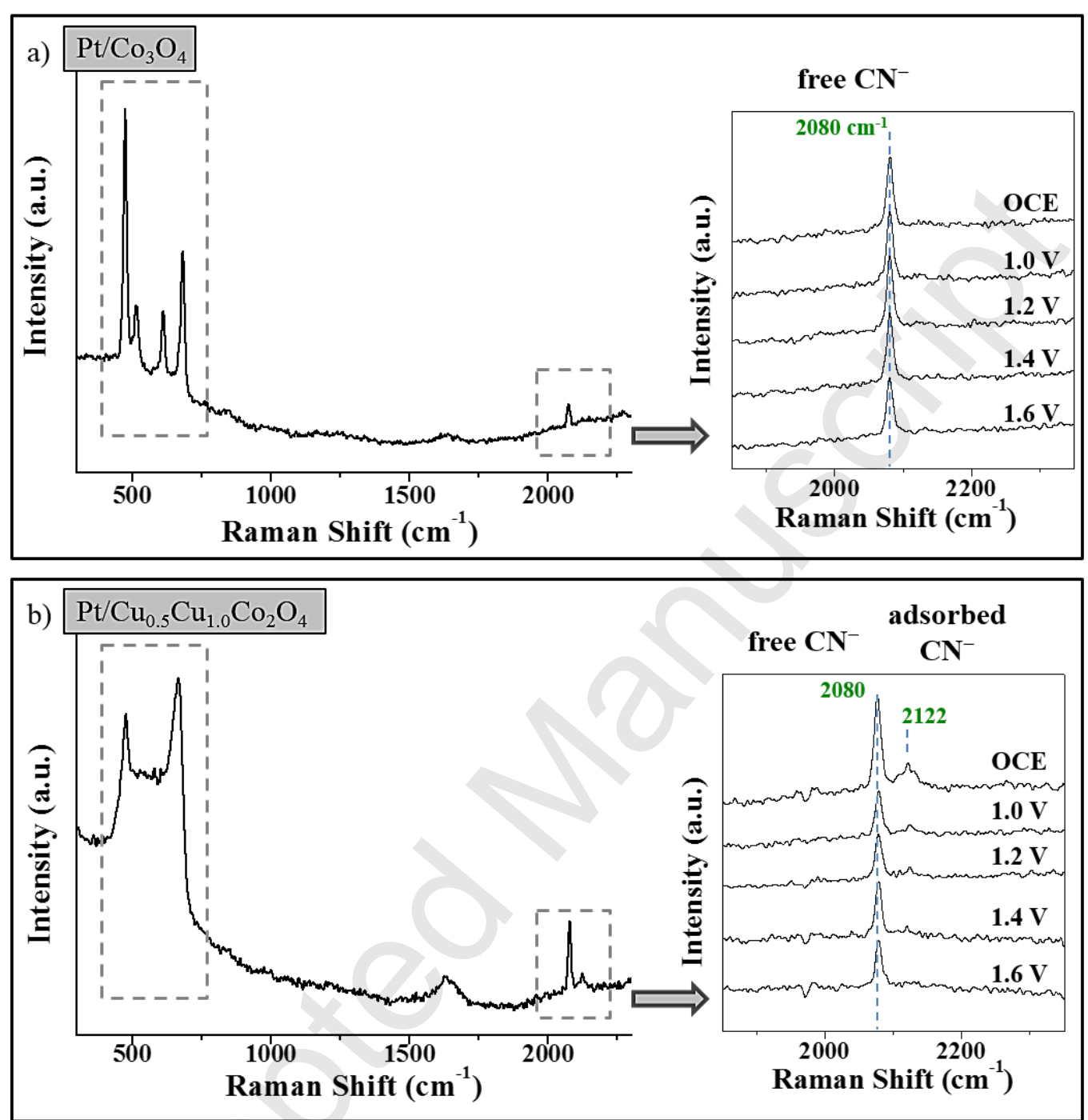

Figure 4. Wide-range Raman spectra of a) $\mathrm{Pt} / \mathrm{Co}_{3} \mathrm{O}_{4}$ and b) $\mathrm{Pt} / \mathrm{Cu}_{0.5} \mathrm{Cu}_{1.0} \mathrm{Co}_{2} \mathrm{O}_{4}$ electrodes at open circuit potential (OCE) in $0.1 \mathrm{M} \mathrm{NaOH}+5000 \mathrm{ppm} \mathrm{CN}^{-}$solution, highlighting the spectral features of metal oxides (on the left) and those of cyanide species (on the right), and their evolution with the applied potential (right inset).

The Raman spectrum of the most active $\left(\mathrm{Cu}_{0.5} \mathrm{Cu}_{1.0} \mathrm{Co}_{2} \mathrm{O}_{4}\right)$ electrode (Fig. $4 \mathrm{~b}$ ) shows marked differences with respect to that of the spinel without copper. On the one hand, only two bands at 479 and $670 \mathrm{~cm}^{-1}$ are discerned in the lower wavenumber region of the spectrum, which may correspond to the $\mathrm{E}_{\mathrm{g}}$ and $\mathrm{A}_{1 \mathrm{~g}}$ modes observed for $\mathrm{Co}_{3} \mathrm{O}_{4}$ (Fig. 4a). These bands, however, are slightly shifted towards lower wavenumbers and their relative intensity is the opposite. Such a significant influence of $\mathrm{Cu}$ on the Raman spectrum may be attributed to the incorporation of $\mathrm{Cu}$ 
in the cobalt spinel, in agreement with previous results [40]. Accordingly, the other two bands of spinel are probably not discerned because they overlap with different $\mathrm{Cu}-\mathrm{O}$ vibration modes in the spinel structure or in segregated copper oxide phases, which show vibration bands between 500 and $635 \mathrm{~cm}^{-1}[51,52]$.

At higher wavenumbers the spectrum presents, besides the band of free cyanide at $2080 \mathrm{~cm}^{-1}$, a new undefined broad band of low intensity between $2108-2130 \mathrm{~cm}^{-1}$ (inset of Fig. 4b). The Raman spectroscopy of cyanide and cyano complexes on thin film cobalt and copper (metal) electrodes has been widely studied before [50,53]. However, little is known on the Raman response of cyanide over cobalt and copper oxides. It is known that the frequency of $\mathrm{CN}$ stretching vibration generally increases on coordination, and the higher the oxidation state of the metal atom bonded to cyanide, the higher the CN stretching frequency [49]. As a consequence, the higher frequency of this new band may indicate that it is related to $\mathrm{Cu}-(\mathrm{CN})_{\mathrm{n}}$ species close to or on the electrode surface [50,53]. The position of the band (between $2108-2130 \mathrm{~cm}^{-1}$ ) suggests the adsorption of cyanide on $\mathrm{Cu}^{2+}$ ions on the surface of the oversaturated spinel. However, the formation (by cyanide-induced copper extraction) and adsorption of $\left[\mathrm{Cu}-(\mathrm{CN})_{\mathrm{n}}\right]$ complexes on the surface of this electrode should not be ruled out, since the $\mathrm{CN}$ stretching of adsorbed $\left[\mathrm{Cu}(\mathrm{CN})_{\mathrm{n}}\right]$ complexes is higher than that when present in solution [50]. Nevertheless, this possibility does not seem very likely, because the extraction of $\mathrm{Cu}$ (the observed active component in the spinels) would have inevitably led to an unstable and detrimental electrocatalytic response that was not observed during voltammetric and electrolytic experiments.

The intensity of the new band starts to decrease above $1.0 \mathrm{~V}$ and it completely vanishes at 1.6 $\mathrm{V}$. This potential range coincides with the onset and the course of cyanide electro-oxidation, with an overlapped peak at around 1.40-1.45 V, observed by CV for this electrode (Fig. 1f). 
These results suggest that a specific adsorption of $\mathrm{CN}^{-}$on $\mathrm{Cu}$ species could be involved in the observed high catalytic performance of $\mathrm{Ti} / \mathrm{Cu}_{\mathrm{x}} \mathrm{Co}_{3-\mathrm{x}} \mathrm{O}_{4}$ electrodes towards $\mathrm{CN}^{-}$electro-oxidation. Nevertheless, it is still premature to unequivocally attribute the catalytic effect to either lattice$\mathrm{Cu}$ or to copper in segregated oxide phase in $\mathrm{Ti} / \mathrm{Cu}_{\mathrm{x}} \mathrm{Co}_{3-\mathrm{x}} \mathrm{O}_{4}$ electrodes, because both $\mathrm{Cu}-$ substituted spinels forming solid solutions (like $\mathrm{x}=0.8$ and 1.0) and oversaturated spinel, containing both lattice (in $\mathrm{Co}$ spinel) and segregated $(\mathrm{CuO})$ copper have also shown great catalytic activity.

\subsection{1. $\mathrm{CN}^{-}$oxidation on $\mathrm{Cu}_{\mathrm{x}} \mathrm{Co}_{3-\mathrm{x}} \mathrm{O}_{4}$ with $\mathrm{x}=0.8$}

In presence of cyanide, the spectrum of this anode shows only the band at $2080 \mathrm{~cm}^{-1}$ (Figure 5a), which is unaffected by the electrode potential and, therefore, assigned to free cyanide in solution. This behavior is similar to that of $\mathrm{Co}_{3} \mathrm{O}_{4}$ (Fig. 4a). However, the lack of a specific band (interaction) of $\mathrm{CN}^{-}$on the spectrum of $\mathrm{Cu}_{0.8} \mathrm{Co}_{2.2} \mathrm{O}_{4}$ seems to be in disagreement with the observed much higher electrochemical activity of this anode compared to $\mathrm{Co}_{3} \mathrm{O}_{4}$. Considering the lower amount of $\mathrm{Cu}$ species on the surface of $\mathrm{Cu}_{0.8} \mathrm{Co}_{2.2} \mathrm{O}_{4}$, than in the oversaturated spinel, surface enhanced Raman effects were investigated by supporting the oxide on a roughened $\mathrm{Au}$ electrode. The Raman profile in the wavenumbers region of metal oxide lattice vibrations was very similar when the Cu-Co mixed spinel was formed on either Pt or Au (see Supp. Info), thereby suggesting that the substrate has little influence on the chemical composition and structural properties of the oxide coating. 

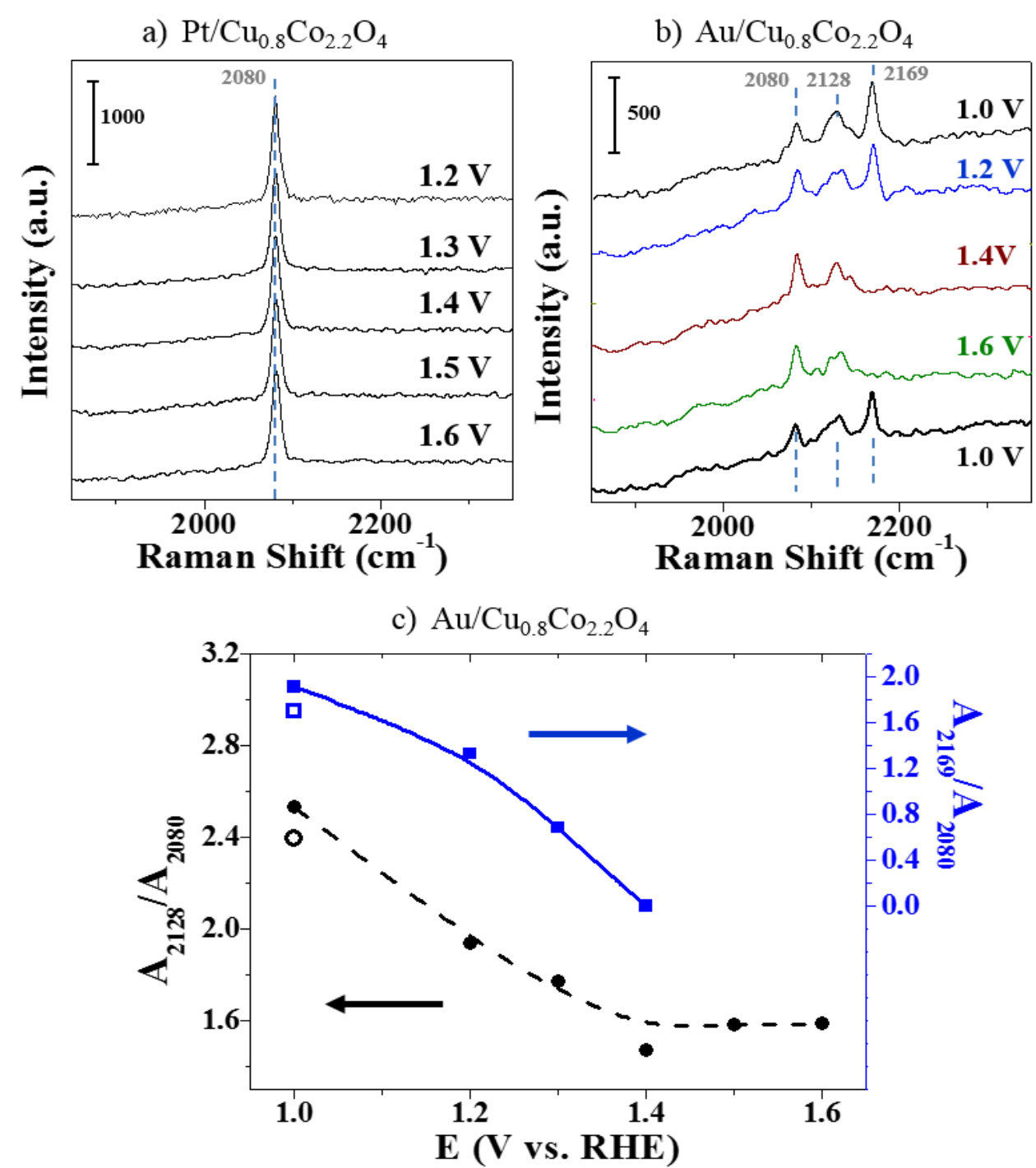

Figure 5. Raman spectra (region of cyanide species) of $\mathrm{Cu}_{0.8} \mathrm{Co}_{2.2} \mathrm{O}_{4}$ supported on (a) $\mathrm{Pt}$ and (b) roughened $\mathrm{Au}$ at different potentials. (c) Effect of the electrode potential on the relative area of the deconvoluted bands for the $\mathrm{Au} / \mathrm{Cu}_{0.8} \mathrm{Co}_{2.2} \mathrm{O}_{4}$ electrode (empty symbols correspond to the electrode returned to $1.0 \mathrm{~V}$ ). Electrolyte $=0.1 \mathrm{M} \mathrm{NaOH}+5000 \mathrm{ppm} \mathrm{CN}^{-}$.

A great effect is observed in the region of cyanide species (Figure 5b). Apart from the band of free $\mathrm{CN}^{-}$at $2080 \mathrm{~cm}^{-1}$, this region of the spectrum shows a clear broad band centered at ca. 2128 $\mathrm{cm}^{-1}$ and a new well-defined and intense band at $2169 \mathrm{~cm}^{-1}$.

As mentioned above, literature on the analysis of this kind of electrodes by Raman and SERS is scarce. Then, the assignment of bands is complex. The broad band at ca. $2128 \mathrm{~cm}^{-1}$ seems to be closely related to that observed for the oversaturated spinel (Figure $4 \mathrm{~b}$ ) and is assigned to 
adsorbed cyanide like $\mathrm{Cu}-(\mathrm{CN})_{\mathrm{n}}$ species, but in this case it appears with considerably higher relative intensity than that of free $\mathrm{CN}^{-}$in solution. Similarly, the bands related to the metal oxide showed also a higher relative intensity when it was supported on the roughened Au (Supp. Info.). These results clearly indicate that the Raman signal has been greatly enhanced on the surface of the oxide, like in the case of the well-known surface enhanced Raman spectroscopy (SERS), by surface plasmon resonance on the roughened Au support [44]. Note that the oxidized copper (in the spinel) cannot produce SERS effect. On the other hand, the intense band at $2169 \mathrm{~cm}^{-1}$ may be attributed to the formation of $\mathrm{Au}-\mathrm{CN}^{-}$and/or $\mathrm{Au}(\mathrm{CN})_{2}{ }^{-}$complex [54,55], prior to $\mathrm{CN}^{-}$oxidation, at uncovered parts of the roughened support [44].

Figure $5 \mathrm{~b}$ also displays the evolution of these bands with the electrode potential. It can be highlighted that the broad band was greatly affected by the electrode potential. Nevertheless, considering that this broad band may contain the contribution of various $\mathrm{Cu}-(\mathrm{CN})_{n}$ species [50,53], their accurate distinction and assignment may be complex. Most significantly, the relative intensity of the broad band starts to decrease from $1.2 \mathrm{~V}$ (Figure $5 \mathrm{c}$.). This potential range coincides with those observed by cyclic voltammetry for the onset of $\mathrm{CN}^{-}$electrooxidation on $\mathrm{Ti} / \mathrm{Cu}_{0.8} \mathrm{Co}_{2.2} \mathrm{O}_{4}$ (Figure 1d-f) or a $\mathrm{Cu}$ electrode (see Supp. Info.). These results confirm that a specific adsorption of $\mathrm{CN}^{-}$on lattice- $\mathrm{Cu}(\mathrm{Cu}$ incorporated into the cobalt spinel structure) is involved in the mechanism of the observed electrocatalytic performance of $\mathrm{Ti} / \mathrm{Cu}_{\mathrm{x}} \mathrm{Co}_{3-\mathrm{x}} \mathrm{O}_{4}$ electrodes towards $\mathrm{CN}^{-}$oxidation.

Above $1.4 \mathrm{~V}$, the intense band at $2169 \mathrm{~cm}^{-1}$ completely disappears, but a residual broad band $\left(2120-2148 \mathrm{~cm}^{-1}\right)$ remains on the spectrum (Figure 5b-c). Finally, once the electrode potential is returned to the initial value $(1.0 \mathrm{~V})$, the first spectrum prior to $\mathrm{CN}^{-}$electro-oxidation is practically recovered (Figure $5 \mathrm{~b}-\mathrm{c}$ ). The former fact is assigned to the electro-oxidation of $\mathrm{CN}^{-}$ on gold support, which occurs at similar potentials to those found for copper electrode (see Supp. Info.). The remaining undefined band may be associated to any product of cyanide oxidation, 
although the irreversible adsorption of cyanide on inactive surface sites should not be ruled out. Experimental and theoretical works have established that cyanate (OCN) adsorbs on metals linearly and perpendicularly to the surface, as a terminal ligand, bonded via the $\mathrm{N}$ atom $[56,57]$. On $\mathrm{Cu}(100)$, the frequency of the asymmetric $\mathrm{CN}$ stretching characteristic of this N-bonded cyanate is $2160-2200 \mathrm{~cm}^{-1}$ [57]. Such a band was found to appear in FTIR spectra upon cyanide oxidation on various metals including $\mathrm{Cu}[58,59]$. By contrast, this band is absent in the Raman spectra obtained in the present work with $\mathrm{Cu}_{\mathrm{x}} \mathrm{Co}_{3-\mathrm{x}} \mathrm{O}_{4}$ at high potentials (Fig. 5b). It is generally accepted that the exact shift in the absorption frequency of adsorbed cyanate is dependent both on the electronic properties (nature) of the surface and on coverage effects $[56,57,60]$. In this sense, the observed discrepancy could be explained if one regards the occurrence of any other possible adsorption mode of cyanate on these oxide electrodes. Density functional theory (DFT) calculations also predicted various types of side-on adsorption of OCN on $\mathrm{Cu}$ (100) with vibrational frequencies of $2120-2160 \mathrm{~cm}^{-1}$ [56]. Although not found experimentally on bare $\mathrm{Cu}$ electrode, this type of side-on bonded cyanate could be formed by cyanide electro-oxidation on the surface of the $\mathrm{Cu}_{\mathrm{x}} \mathrm{Co}_{3-\mathrm{x}} \mathrm{O}_{4}$ spinel. Unfortunately its vibrational frequency lies in the same interval than that for surface $\mathrm{Cu}-(\mathrm{CN})_{\mathrm{n}}$-like species, so making it uncertain the real occurrence of such cyanate adsorption mode. Another reason for the lack of any clear band related to adsorbed cyanate is that cyanate ions were displaced by $\mathrm{OH}^{-}$ions in alkaline medium [60].

\section{Discussion}

It is well known that the activity of a given metal oxide is determined by the nature of the cation [61]. In the case of $\mathrm{Co}_{3} \mathrm{O}_{4}$ and other common spinels, $\mathrm{M}^{3+}$ species occupying octahedral sites show significant activity, whereas $\mathrm{M}^{2+}$ species seem to play a secondary role. These $\mathrm{M}^{3+}$ species are responsible of the well-known "active" behavior of $\mathrm{Co}_{3} \mathrm{O}_{4}$, in which surface $\mathrm{Co}$ (III) 
$\leftrightarrow \mathrm{Co}(\mathrm{IV})$ solid-state transitions govern the electrochemical reactions occurring at high potentials, like the electro-oxidation of $\mathrm{CN}^{-}[36,37]$ and the OER $[14,61]$. Thus, the absence of discernible and potential-sensitive bands associated to any interaction between Co and $\mathrm{CN}^{-}$ observed in this work (Figures 4 and 5) is in agreement with the formation of $\mathrm{CoO}_{2}$ and its subsequent participation in the electrochemical-chemical (EC) two-step $\mathrm{CN}^{-}$electro-oxidation mechanism envisaged as follows:

$$
\begin{aligned}
& \mathrm{CoOOH}+\mathrm{OH}^{-} \rightleftarrows \mathrm{CoO}_{2}+\mathrm{H}_{2} \mathrm{O}+e^{-} \\
& \mathrm{CN}^{-}+2 \mathrm{CoO}_{2}+\mathrm{H}_{2} \mathrm{O} \rightarrow \mathrm{CNO}^{-}+2 \mathrm{CoOOH}
\end{aligned}
$$

Besides $\mathrm{CN}^{-}$electro-oxidation (Eq. 10), surface $\mathrm{CoO}_{2}$ can react to evolve oxygen:

$$
2 \mathrm{CoO}_{2}+2 \mathrm{OH}^{-} \rightarrow 2 \mathrm{CoOOH}+\mathrm{O}_{2}+2 e^{-}
$$

with equation (7) as overall reaction of (9) and (11). In this sense, and because both (10) and (11) are competing reactions, the high activity of $\mathrm{Co}_{3} \mathrm{O}_{4}$ electrodes for the OER in alkaline media [61] and the lack of cyanide specific interaction (Figs. 4 and 5) may be responsible for the poor current efficiency obtained for $\mathrm{CN}^{-}$electro-oxidation on $\mathrm{Co}_{3} \mathrm{O}_{4}$ (Table 1).

On the contrary, the obtained results show that the introduction of copper remarkably increases the electroactivity of cobalt spinel towards $\mathrm{CN}^{-}$electro-oxidation. Although an increase in the electrical conductivity of the mixed oxides could occur, the quite similar cyclic voltammograms obtained for the different oxides (Fig. 1) suggests that this fact may not be significant to explain the much better catalytic performance of $\mathrm{Cu}_{\mathrm{x}} \mathrm{Co}_{3-\mathrm{x}} \mathrm{O}_{4}$ electrodes.

In-situ Raman and surface enhanced Raman characterizations reveal the formation of $\mathrm{Cu}$ $(\mathrm{CN})_{\mathrm{n}}$ species on the surface of $\mathrm{Cu}_{\mathrm{x}} \mathrm{Co}_{3-\mathrm{x}} \mathrm{O}_{4}$ electrodes and their oxidation at potentials similar to those observed by cyclic voltammetry (around $1.2-1.4 \mathrm{~V}$ ). These results indicate that an specific (electro)adsorption of $\mathrm{CN}^{-}$ions on surface $\mathrm{Cu}$ species occurs prior to electro-oxidation. Hence, the electrocatalytic oxidation of $\mathrm{CN}^{-}$promoted by $\mathrm{Cu}$ on $\mathrm{Cu}_{\mathrm{x}} \mathrm{Co}_{3-\mathrm{x}} \mathrm{O}_{4}$ electrodes may proceed through a different mechanism, in which the electrocatalytic effect seems to be related, 
unlike in common spinels, to $\mathrm{M}^{2+}$ species (for the adsorption of cyanide and/or the participation of the $\mathrm{M}^{2+} / \mathrm{M}^{3+}$ redox couple).

The electrocatalytic effect of copper on $\mathrm{CN}^{-}$oxidation in alkaline media has been previously studied and different mechanisms have been reported depending on the conditions used ( $\mathrm{pH}$, cyanide and copper concentrations, cell design and operating conditions) [11,23-28,31,32,62]. Some authors proposed that the electro-oxidation of cyanide is catalyzed by copper cyanide complexes, either in solution [62] or involving a surface adsorbed intermediate [23,25,32], through the $\mathrm{Cu}(\mathrm{II})-\mathrm{Cu}(\mathrm{I})$ redox couple as electron transfer mediator.

On the other hand, various reports studied the electrocatalytic activity of electrodeposited copper oxide films for $\mathrm{CN}^{-}$electro-oxidation [11,23-28,31,32]. In this case, the catalytic effect was attributed to the formation of active copper(III) species in the oxide film (in the form of $\mathrm{CuO}(\mathrm{OH})$ and/or $\left.\mathrm{Cu}_{2} \mathrm{O}_{3}\right)$, with the $\mathrm{Cu}(\mathrm{III})-\mathrm{Cu}(\mathrm{II})$ redox couple as electron transfer mediator [11] However, the mechanism is also controversial. One possibility is the electrochemical-chemical (EC) two-step electro-oxidation mechanism without specific $\mathrm{CN}^{-}$adsorption, like that of $\mathrm{Co}_{3} \mathrm{O}_{4}$ (see reactions 9 and 11), driven by the $\mathrm{Cu}(\mathrm{III})-\mathrm{Cu}(\mathrm{II})$ redox couple [11].

A second possible mechanism was postulated by Wels and Johnson [11], who proposed that the oxidation of $\mathrm{CN}^{-}$with oxygen transfer is driven by $\left({ }^{\circ} \mathrm{OH}\right)_{\text {ads }}$ generated at $\mathrm{Cu}(\mathrm{III})$ sites. Nevertheless, several studies (for example those working with $\mathrm{BDD}$ or $\mathrm{PbO}_{2}$ anodes) showed that the mere generation of catalytic sites for ${ }^{\circ} \mathrm{OHs}$ is not sufficient to catalyze cyanide oxidation. As a result, in the same work the authors further inferred that electrocatalysis may require the adsorption of the reactant, cyanide, on surface sites together with ${ }^{\circ} \mathrm{OHs}$.

The obtained results suggest that the mechanism of $\mathrm{CN}^{-}$electroxidation on $\mathrm{Cu}_{\mathrm{x}} \mathrm{Co}_{3-\mathrm{x}} \mathrm{O}_{4}$ electrodes may have some of the features explained above. First, the interference of cathodic peaks after electro-oxidation observed in Fig. 1, together with the fact that this interference 
becomes greater with the $\mathrm{Cu}$ content; clearly points to the participation of highly oxidant surface species in a mediated electro-oxidation of $\mathrm{CN}^{-}$. This would rule out the oxidation by $\left({ }^{\circ} \mathrm{OH}\right)_{\text {ads }}$ generated at $\mathrm{Cu}$ (III) sites, which is in agreement with the onset of $\mathrm{CN}^{-}$electro-oxidation at potentials considerably lower than the OER (Fig. 1). Second, Raman characterization demonstrates that $\mathrm{CN}^{-}$ions are specifically adsorbed on surface $\mathrm{Cu}$ species prior to electrooxidation. Consequently, we propose that on $\mathrm{Cu}_{\mathrm{x}} \mathrm{Co}_{3-\mathrm{x}} \mathrm{O}_{4}$ electrodes the reaction proceeds through mediated electro-oxidation of copper-adsorbed cyanide. Nevertheless, the nature of the mediator still remains uncertain. Since $\mathrm{CN}^{-}$electro-oxidation on $\mathrm{Cu}_{\mathrm{x}} \mathrm{Co}_{3-\mathrm{x}} \mathrm{O}_{4}$ electrodes occurs at potentials below and equal to those of $\mathrm{Co}(\mathrm{III})-\mathrm{Co}(\mathrm{IV})$ redox couple (peak $\mathrm{A}_{2} / \mathrm{C}_{2}$ in Figure 1), in principle it is expected that both the $\mathrm{Cu}(\mathrm{II})-\mathrm{Cu}(\mathrm{III})$ and $\mathrm{Co}(\mathrm{III})-\mathrm{Co}(\mathrm{IV})$ redox couples in the mixed oxide could act as electron and oxygen transfer mediators.

The proposed electro-oxidation mechanism without the participation of radicals easily explains the much higher current efficiencies for $\mathrm{CN}^{-}$electro-oxidation and the rapid efficiency increase with the $\mathrm{Cu}$ content (Table 1): the higher the $\mathrm{Cu}$ doping level the higher the amount of surface copper-cyano complexes. Thus, as soon as they are generated, the oxidized electron mediator species can readily react with copper-adsorbed cyanide available on the anode surface. This is in agreement with the decrease in the electro-oxidation potential with copper content observed in Figure 1. Such a progressive decrease and separation of the $\mathrm{CN}^{-}$electro-oxidation potential respect to that of the competing OER, i.e. true electrocatalytic effect, results in a gradually increasing current efficiency. On the other hand, the reaction of copper-adsorbed cyanide with neighbouring mediators may explain the formation of side-on bonded instead of N-bonded cyanate, as suggested by Raman spectroscopy.

Apart from activity, the stability of electrodes becomes crucial from a practical point of view. As stressed in the introduction section, this aspect is particularly relevant for copper and copper 
oxides, which usually suffer from low consistency and stability. In fact, for comparison purposes we tried to prepare a Ti-supported copper oxide electrode by using the same preparation method to that described in section 2.1 and a $0.5 \mathrm{M} \mathrm{Cu}\left(\mathrm{NO}_{3}\right)_{2}$ ethanol solution. However, it was not possible to apply more than 10 deposition steps without spontaneous exfoliation of the coating, thus, preventing the oxide to form a sufficiently thick layer to cover the Ti substrate adequately. Such a low adherence, together with the high electrical resistivity of this oxide $(60 \Omega \mathrm{m}$ for $\mathrm{CuO}$ [63] compared to that of $\mathrm{Co}_{3} \mathrm{O}_{4}=0.47 \Omega \mathrm{m}$ [64]), restricts its electrochemical application.

By stark contrast, the $\mathrm{Cu}_{\mathrm{x}} \mathrm{Co}_{3-\mathrm{x}} \mathrm{O}_{4}$ mixed oxides with spinel structure prepared in this work show high robustness and electrochemical stability. This latter property was previously examined in accelerated tests (galvanostatic treatments at $100 \mathrm{~mA} \mathrm{~cm}^{-2}$ in $1 \mathrm{M} \mathrm{NaOH}$ solution) $[40,41]$. Although the service life decreases with the introduction of $\mathrm{Cu}$, all the studied $\mathrm{Cu}_{\mathrm{x}} \mathrm{Co}_{3}$ ${ }_{\mathrm{x}} \mathrm{O}_{4}$ electrodes successfully worked, under these demanding conditions, for $4000-6000 \mathrm{~h}$ before deactivation. The values of service life for the different $\mathrm{Cu}_{\mathrm{x}} \mathrm{Co}_{3-\mathrm{x}} \mathrm{O}_{4}$ electrodes, expressed as the ratio of the total charge passed to the oxide loading, range between $115-180 \mathrm{~A} \mathrm{~h} \mathrm{mg}^{-1}$ (Table 1), which lies in the order of the most stable DSA-like electrodes ever reported for alkaline conditions [22].

\section{Conclusions}

The voltammetric characterization and electrolytic experiments of Ti-supported $\mathrm{Cu}_{\mathrm{x}} \mathrm{Co}_{3-\mathrm{x}} \mathrm{O}_{4}$ electrodes (with $0 \leq \mathrm{x} \leq 1.5$ ) presented in this work clearly shows that the incorporation of $\mathrm{Cu}$ into the cobalt spinel rapidly increases the catalytic activity, efficiency and kinetics of this electrode towards $\mathrm{CN}^{-}$electro-oxidation. Unexpectedly for this type of active oxides, the current efficiency for cyanide oxidation increases up to $100 \%$ when the amount of $\mathrm{Cu}$ reaches or overcomes that of the saturation of the spinel structure $(x=1.0$ or 1.5$)$. Thus, these electrodes 
can eliminate cyanide completely under charge-transfer regime in aqueous environment (at least at $5 \mathrm{~mA} \mathrm{~cm}^{2}$ ).

The novel study carried out by in-situ Raman and surface enhanced Raman spectroscopies enables observation of the formation and oxidation of $\mathrm{Cu}-(\mathrm{CN})_{\mathrm{n}}$ species on the surface of $\mathrm{Cu}_{\mathrm{x}} \mathrm{Co}_{3-\mathrm{x}} \mathrm{O}_{4}$ electrodes. These results indicate that, unlike the case of $\mathrm{Co}_{3} \mathrm{O}_{4}$, the specific (electro)adsorption of $\mathrm{CN}^{-}$ions on surface $\mathrm{Cu}$ species is involved in the electrocatalytic oxidation mechanism of $\mathrm{Cu}_{\mathrm{x}} \mathrm{Co}_{3-\mathrm{x}} \mathrm{O}_{4}$ electrodes.

Considering that the oversaturated spinel electrochemically behaves like $\mathrm{CuO}$, the obtained results suggest that the electrochemical activity of $\mathrm{Cu}_{\mathrm{x}} \mathrm{Co}_{3-\mathrm{x}} \mathrm{O}_{4}$ electrodes (with $\mathrm{x}=0.8-1.0$ ) approaches that of copper oxide, at least for $\mathrm{CN}^{-}$electro-oxidation. However, unlike copper and copper oxides, the different $\mathrm{Cu}_{\mathrm{x}} \mathrm{Co}_{3-\mathrm{x}} \mathrm{O}_{4}$ electrodes show excellent robustness and electrochemical stability in alkaline conditions. Hence, the incorporation of copper into cobalt oxide is demonstrated to be an excellent approach to obtain highly active and robust copperbased electrocatalysts for feasible practical application.

\section{Acknowledgements}

Financial support from the Spanish Ministerio de Economía y Competitividad and FEDER funds (MAT2016-76595-R, IJCI-2014-20012) and from the Generalitat Valenciana (PROMETEO2013/038) is gratefully acknowledged.

\section{References}

1. A. Kubacka, R. Si, P. Michorczyk, A. Martínez-Arias, W. Xu, J. C. Hanson, J. A. Rodriguez, M. Fernández-García. Appl. Catal. B: Environ. 132-133 (2013) 423-432.

2. I. P. Beletskaya, A. V. Cheprakov. Coord. Chem. Rev. 248 (2004) 2337-2364.

3. R. Poreddy, C. Engelbrekt, A. Riisager. Catal. Sci. Technol. 5 (2015) 2467-2477.

4. U. R. Pillai, S. Deevi. Appl. Catal. B: Environ. 64 (2006) 146-151. 
5. W. Wang, S. Wang, X. Ma, J. Gong. Chem. Soc. Rev. 40 (2011) 3703-3727.

6. J. Du, Z. Chen, S. Ye, B. J. Wiley, T. J. Meyer. Angew. Chem. Int. Ed. 54 (2015) 2073 -2078.

7. D. Ren, Y. Deng, A. D. Handoko, C. S. Chen, S. Malkhandi, B. S. Yeo. ACS Catal. 5 (2015) 2814-2821.

8. J. Zhao, P. D. Tran, Y. Chen, J. S. C. Loo, J. Barber, Z. J. Xu. ACS Catal. 2015, 5, 4115-4120.

9. J. Qiao, M. Fan, Y. Fu, Z. Bai, C. Ma, Y. Liu, X-D. Zhou. Electrochim. Acta 153 (2015) 559-565.

10. G. Zhao, W. Wang, T.-S. Bae, S.-G. Lee, C. Mun, S. Lee, H. Yu, G.-H. Lee, M. Song, J. Yun. Nat. Commun. 6:8830 (2015).

11. B. Wels and D. C. Johnson. J. Electrochem. Soc. 9 (1990) 2785-2791.

12. J. Azevedo, L. Steier, P. Dias, M. Stefik, C. T. Sousa, J. P. Araújo, A. Mendes, M. Graetzel, S. D. Tilley. Energy Environ. Sci., 7 (2014) 4044-4052.

13. X. Liu, S. Cui, Z. Sun, Y. Ren, X. Zhang, P. Du. J. Phys. Chem. C 120 (2016) 831-840.

14. Ch. Comninellis, G. Chen (Eds). Electrochemistry for the Environment. Springer Science \& Business Media, New York. 2009.

15. U.S. EPA. IRIS Toxicological Review of Hydrogen Cyanide and Cyanide Salts (Interagency Science Discussion Draft). U.S. Environmental Protection Agency, Washington, DC, EPA/635/R-08/016D, 2010.

16. D. A. Dzombak, R. S. Ghosh, G. M. Wong-Chong (Eds.). Cyanide in Water and Soil Chemistry, Risk, and Management. CRC Press/Taylor \& Francis Group. Boca Raton, FL, 2006.

17. A. Rubo, R. Kellens, J. Reddy, N. Steier, W. Hasenpusch. Alkali Metal Cyanides. Ullmann's Encyclopedia of Industrial Chemistry. John Wiley and Sons, Inc. 2006

18. J. M. Monteagudo, L. Rodríguez, J. Villaseñor. J. Chem. Technol. Biotechnol. 79 (2004) 117-125.

19. Appendix A to Part 423 - 126 Priority Pollutants, in Code of Federal Regulations (United States).

Title 40 - Protection of Environment. Vol. 29, 2014.

20. Directive 2008/105/EC of the European Parliament and of the Council on Environmental Quality Standards.

21. R. R. Dash, A. Gaur, C. Balomajumder. J. Hazardous Materials 163 (2009) 1-11.

22. R. Berenguer, J. M. Sieben, C. Quijada, E. Morallón. Appl. Catal. B: Environ. 199 (2016) 394-404.

23. C. S. Hofseth, T. W. Chapman. J. Electrochem. Soc. 146 (1999) 199-207.

24. A. Socha, E. Kuśmierek, E. Chrześcijańska. J. Appl. Electrochem. 32 (2002) 409-414.

25. J. Lu, D. B. Dreisinger, W. C. Cooper. J. Appl. Electrochem. 32 (2002) 1119-1129.

26. R. M. Felix-Navarro, S. W. Lin, A. B. Castro-Ceceña, J. A. Casco-Carrete. J. Electrochem. Soc. 150 (2003) D149-D154.

27. L. Szpyrkowicz, S.N. Kaul, E. Molga, M. DeFaveri. Electrochimica Acta 46 (2000) 381-387.

28. J.-Y. Hwang, Y.-Y. Wang, C.-C. Wan. J. Appl. Electrochem. 17 (1987) 684-694.

29. G. H. Kelsall, S. Savage D. Brandt. J. Electrochem. Soc. 138 (1991) 117-124. 
30. P. Cañizares, M. Díaz, J. A Domínguez, J. Lobato, M. A Rodrigo. J. Chem. Technol. Biotechnol. 80 (2005) 565-573.

31. F. Hine, M. Yasuda, T. Iida, Y. Ogata. Electrochim. Acta 31 (1986) 1389-1395.

32. S.C. Cheng, M. Gattrell, T. Guena, B. MacDougall, Electrochim. acta 47 (2002) 3245-3256.

33. M. R. V. Lanza, R. Bertazzoli. Ind. Eng. Chem. Res. 41 (2002) 22-26.

34. C. S. Fugivara, P. T. A. Sumodjo, A. A. Cardoso, A. V. Benedetti. Analyst 121 (1996) 541-545.

35. H. Xu, A. Li, L. Feng, X. Cheng, S. Ding. Int. J. Electrochem. Sci., 7 (2012) 7516-7525.

36. A. Stavart, A. Van Lierde, J. Applied Electroch. 31 (2001) 469-474.

37. R. Berenguer, T. Valdés-Solís, A. B. Fuertes, C. Quijada, E. Morallón. J. Electrochem. Soc. 155 (2008) K110-K115.

38. F. Chena, X. Zhao, H. Liu, J. Qu. Appl. Catal. B: Environ. 158-159 (2014) 85-90.

39. S. Tian, Y. Li, X. Zhao. Electrochim. Acta 180 (2015) 746-755.

40. A. La Rosa-Toro, R. Berenguer, C. Quijada, F. Montilla, E. Morallón, J. L. Vázquez. J. Phys. Chem. B 2006, 110, 24021-24029.

41. R. Berenguer, A. La Rosa-Toro, C. Quijada, and E. Morallón. J. Phys. Chem. C 2008, 112, 1694516952.

42. APHA Method 4500-CN. Standard Methods for the Examination of Water and Wastewater. American Public Health Association.

43. R. Gómez, J. M. Pérez, J. Solla-Gullón, V. Montiel, A. Aldaz, J. Phys. Chem. B 108 (2004) 99439949.

44. Z.-Q. Tian, B. Ren, D.-Y. Wu, J. Phys. Chem. B 106 (2002) 9463-9483.

45. N. Kuyucak, A. Akcil. Miner. Eng. 50-51 (2013) 13-29.

46. S. K. Bikkarolla, P. Papakonstantinou. J. Power Sources 281 (2015) 243-251

47. A. Serov, N. I. Andersen, A. J. Roy, I. Matanovic, K. Artyushkova, P. Atanassov. J. Electrochem. Soc. 162 (2015) F449-F454.

48. M. J. Escudero, T. Rodrigo, L. Mendoza, M. Cassir, L. Daza, J. Power Sources 140 (2005) 81-87.

49. K. Nakamoto, "Infrared and Raman Spectra of Inorganic and Coordination Compounds, Part B,", 6th Edition, John Wiley \& Sons, Inc., Hoboken, New Jersey, 2009.

50. M Fleischmann, Z. Q. Tian, L. J. Li, J. Electroanal. Chem. 217 (1987) 397-410.

51. S. T. Mayer, R. H. Muller, J. Electrochem. Soc. 139 (1992) 426-434.

52. M.A. Dar, Q. Ahsanulhaq, Y. S. Kim, J. M. Sohn, W. B. Kim, H. S. Shin, Appl. Surf. Sci. 255 (2009) 6279-6284.

53. B. Merrick, R. Mahoney, R. P. Cooney, J. Chem. Soc. Faraday Trans. 1, 1985, 81, 2123-2130.

54. B. Bozzini, A. Fanigliulo, J. Appl. Electrochem. 32 (2002) 1043-1048.

55. F. Huerta, C. Mele, B. Bozzini, E. Morallón, J. Electroanal. Chem. 569 (2004) 53-60.

56. J. M. Hu, Y. Li, J. Q. Li, Y. F. Zhang, W. Lin, G. X. Jia, J. Solid State Chem. 177 (2004) 2763-2771. 
57. G. R. Garda, R. M. Ferullo, N. J. Castellani, Surf. Sci. 598 (2005) 57-67.

58. L. K. H. K. Alwis, M. R. Mucalo, Electrocatalysis 7 (2016) 104-114.

59. R. M. Souto, F. Ricci, L. Szpyrkowicz, J. L. Rodríguez, E. Pastor, J. Phys. Chem. C 115 (2011) 36713677.

60. M. Bron, R. Holze, J. Electroanal. Chem. 385 (1995) 105-113.

61. S. Trasatti Electrodes of conductive metallic oxides, Part. A. Elsevier Scientific Publishing Company, N.Y. (1980) 236-238.

62. A. Katagiri, S. Yoshimura, S. Yoshizawa. Inorg. Chem. 20 (1981) 4143-4146.

63. D. R. Lide, ed., CRC Handbook of Chemistry and Physics, CRC Press, Boca Raton, FL, 2005.

64. F. Nunes, M.H. Mendonca, M.I. da Silva Pereira, F.M. Costa, Materials Chem. Phys 92 (2005) 526533. 

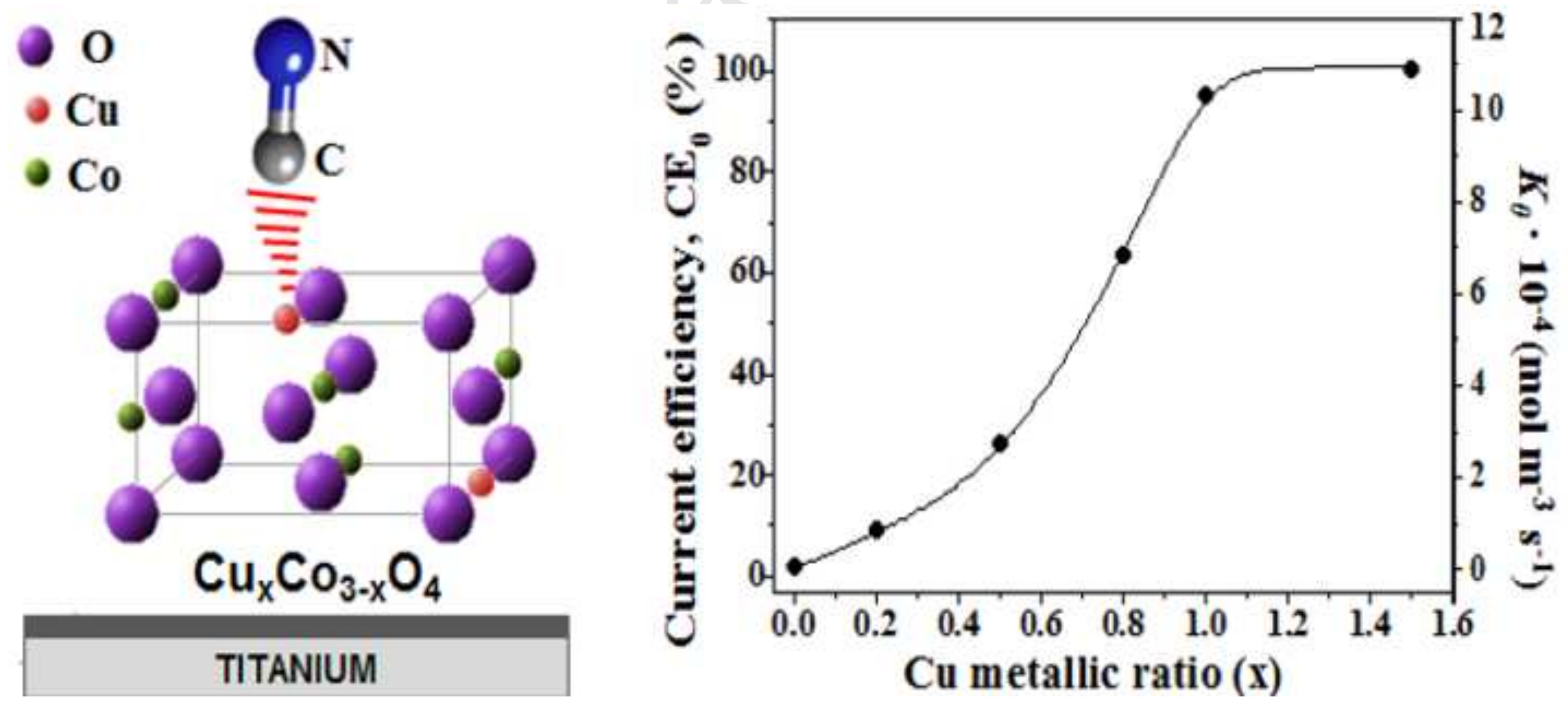


\section{Highlights}

- Cu-doped $\mathrm{Co}_{3} \mathrm{O}_{4}$ electrocatalysts were used for remediation of cyanide waters

- The effect of $\mathrm{Cu}$ content has been analysed in the oxidation of cyanide.

- Cu saturated and oversaturated spinels exhibit $100 \%$ current efficiencies

- In-situ SERS reveals the specific adsorption of $\mathrm{CN}$ - ions on surface $\mathrm{Cu}$. 